THE COST OF WORK-RELATED STRESS TO SOCIETY: A SYSTEMATIC REVIEW

\title{
THE COST OF WORK-RELATED STRESS TO SOCIETY: A SYSTEMATIC REVIEW
}

Juliet Hassard ${ }^{1,2}$, Kevin Teoh ${ }^{1,2}$, Gintare Visockaite ${ }^{2}$, Philip Dewe ${ }^{1,2} \&$ Tom Cox ${ }^{1}$,

1 The Centre for Sustainable Working Life, Birkbeck University of London

${ }^{2}$ Department for Organisational Psychology, Birkbeck University of London

Corresponding Author: Dr Juliet Hassard BA (Hons) MSc PhD, Birkbeck, University of London, Room 210, Clore Management Centre, Malet Street, Bloomsbury, London, WC1E 7HX, England.

E: j.hassard@bbk.ac.uk

T: +44 (0)2076316394 


\begin{abstract}
Objective. A global and systematic review of the available evidence examining the cost of work-related stress would yield important insights into the magnitude and nature of this social phenomenon. The objective of this systematic review was to collate, extract, review, and synthesize economic evaluations of the cost of work-related stress to society.
\end{abstract}

Method. A research protocol was developed outlining the search strategy. Included cost-ofillness (COI) studies estimated the cost of work-related stress at a societal level, and were published in English, French or German. Searches were carried out in ingentaconnect, EBSCO, JSTOR, Science Direct, Web of Knowledge, Google and

Google scholar. Included studies were assessed against ten COI quality assessment criteria.

Results. Fifteen COI studies met the inclusion criteria and were reviewed. These originated from Australia, Canada, Denmark, France, Sweden, Switzerland, the United Kingdom, the United States, and the EU-15. At a national and pan-European level, the total estimated cost of work-related stress in 2014 was observed to be considerable and ranged substantially from US $\$ 221.13$ million to $\$ 187$ billion. Productivity related losses were observed to proportionally contribute the majority of the total cost of work-related stress (between 70 to $90 \%$ ), with healthcare and medical costs constituting the remaining $10 \%$ to $30 \%$.

Conclusion. The evidence reviewed here suggests a sizeable financial burden imposed by work-related stress on society. The observed range of cost estimates across studies was understood to be attributable to variations in definitions of work-related stress; the number and type of costs estimated; and, in how production loss was estimated. It is postulated that the cost estimates identified by this review are likely conservative due to narrow definitions of work-related stress (WRS) and the exclusion of diverse range of cost components. 
Keywords: work-related stress; cost-of-illness study; society; burden of illness; systematic review 


\section{The Cost of Work-Related Stress to Society: A Systematic Review}

Work-related stress has become a major occupational risk factor in all industrialized countries, although comparatively less is known within many newly industrialized and developing countries (Kortum, Leka, \& Cox, 2010). Much has been written about workrelated stress, and investigations conducted to examine and understand its associated human and organizational costs. However, much less attention has been paid to understanding the economic burden of this social and occupational phenomenon. Although small, this growing area of investigation attests to the substantial financial costs associated with psychosocial risks and work-related stress for organizations and national economies (Hoel, Sparks \& Cooper, 2001; Sultan-Taïeb, Chastang, Mansouri \& Niedhammer, 2013).

For many in the field of Occupational Health Psychology (OHP) and beyond, such cost estimates are important (and often highly cited) sources of information. They are frequently used to illustrate and communicate the scale and magnitude of the problem and, in turn, argue the business case for preventative action (Koopmanschap, 1998; Larg \& Moss, 2011). However, detailed evaluations of these costs have seldom received attention in the broader literature; with some frequently cited figures being produced without clear specification or transparency in their employed methodology (e.g., American Institute of Stress, n.d.). There is now an imperative need for OHP, and indeed allied research fields, to develop a stronger empirical understanding of where and how such cost estimates are derived. No study to date, to the knowledge of the authors, has attempted to systematically collate, summarize, review and critique the available economic estimations of work-related stress in the literature. Consequently, the current study aims to address this gap.

\section{Work-related Stress: Causes and Consequences}

Work-related psychosocial risks are concerned with those aspects of work design and the organization and management of work within their social and environmental contexts, which have the potential for causing psychological, social or physical harm (Cox, 
Griffiths \& Rial-Gonzalez, 2000). Exposure to psychosocial risks in the workplace (such as injustice at work, poor organizational climate, poor decision latitude, insufficient leadership, effort-reward imbalance) has been linked to poor mental health (Bonde, 2008; Stansfeld \& Candy, 2006), increased health impairing behaviors (e.g., increased smoking; Kouvonen, Kivimäki, Virtanen, Pentti \& Vahtera, 2005), alcohol consumption (Kouvonen et al., 2008), poor physical health (e.g., coronary heart disease; Kivimäki et al., 2006; Kuper \& Marmot, 2003), and even death (e.g., cardiovascular mortality; Kivimäki et al., 2002). It has also been associated with reduced performance (Sullivan \& Bhagat, 1992; Virtanen et al., 2009) and poorer safety outcomes in the workplace (Spurgeon, Harrington, \& Cooper, 1997; Suzuki et al., 2004). Despite the potential risks posed, work-related stress and exposure to psychosocial risks remain salient characteristics of the modern workplace (see review by Leka \& Jain, 2010).

Results from the Fifth European Working Conditions Survey (Eurofound, 2012) found a significant proportion of workers reported being exposed to numerous psychosocial risks, for example: $62 \%$ of surveyed workers reported working under tight deadlines; $59 \%$ at a fast pace; $51 \%$ experiencing organizational change, and; $24 \%$ working more than 40 hours a week. A survey of 31 European countries found that $40 \%$ of workers felt that stress was not handled or managed well in their workplace (EU-OSHA, 2013). Consequently, the increased recognition of the significant challenge posed by work-related stress and exposure to psychosocial risks within occupational health management is now evident with numerous stakeholders (e.g., the European Agency for Safety and Health at Work, governments and policymakers, researchers) touting these new and emerging risks as a major and global occupational and public health concern (EU-OSHA, 2014; Kortum et al., 2010). 


\section{Cost-of-illness studies}

Alongside epidemiological statistics on mortality and morbidity, understanding the financial cost to society is an important avenue to assess the magnitude and significance of a disease as an occupational and public health issue (Leigh, 2006; Tarricone, 2006). The economic burden of work-related stress is a growing field of inquiry, evidenced by the increasing number of cost-of-illness (COI) studies in this area (LaMontagne, Sanderson \& Cocker, 2010; Levi \& Lunde-Jensen, 1996; Sultan-Taïeb et. al, 2013). COI studies aim to estimate the total economic impact of a disease incurred by all relevant stakeholders within society (Bloom, Canning, \& Sevilla, 2001; Tarricone, 2006). For many in the field of OHP, and probably the broader psychological research community, a comprehensive and critical understanding of the key methodological components and empirical considerations of $\mathrm{COI}$ studies is arguably limited; thus, the meaningful understanding and critical examination of derived figures could be challenging and, potentially, elusive to many. Therefore, the following sections aim to provide a brief descriptive overview of the key components and methodological considerations underpinning such studies.

Methodological approach. COI studies can be broadly grouped into three approaches: top-down, bottom-up, and deductive (Drummond, Sculpher, Torrance, O'Brien, \& Stoddart, 2005; Larg \& Moss, 2011). In general, the deductive approach is less commonly used than top-down or bottom-up approaches (Giga, Hoel, \& Lewis, 2008; Hoel et al., 2001). Top-down approaches operate by aggregating portions of resources from a specific disease or health problem. This involves identifying the proportion of use within particular health services or expenditure by users with a specified disease. For example, Sultan-Taïeb et al. (2013) first estimated the number of mental disorders and coronary heart disease cases attributable to job strain. The burden of these cases on the total medical, sick leave, and value of life costs were then calculated before being aggregated to obtain the total cost of job strain. These approaches are only as good as the quality of secondary data sources used, and often have difficulty distinguishing group differences in consumption and utilization of 
health and economic resources (Larg \& Moss, 2011). Despite this, top-down approaches are typically quicker and easier to conduct than bottom-up approaches as the former often relies solely on secondary data (Mogyorosy \& Smith, 2005).

In contrast, bottom-up approaches take the estimated cost per case of work-related stress and extrapolate it to the national level. In this instance, medical expenditure and/or loss of productivity are costed per person or per case, and then multiplied by the number of cases or persons affected (Giga et al., 2008; Larg \& Moss, 2011). Its strength lies in the possibility of identifying all relevant cost components for each specific case or person (Wordsworth, Ludbrook, Caskey \& Macleod, 2005). However, the lack of appropriate data sources can make thorough calculations time consuming or even, in some case, not feasible (Larg \& Moss, 2011; Mogyorosy \& Smith, 2005).

Finally, the deductive approach examines the proportion of costs associated with work-related stress as obtained from the research literature, and applies this to a total estimate of work-related illness or productivity (Giga et al., 2008). For example, if workrelated stress was thought to constitute $10 \%$ of the total cost of work-related ill-health (estimated to be a hypothetical $\$ 100$ billion), the estimated costs of stress would, therefore, be $\$ 10$ billion. The strength of the deductive approach lies in its simplicity. The main issue with the deductive approach is that it assumes the breakdown and the average cost of workrelated stress are identical to the average cost of work-related ill-health (EU-OSHA, 1999).

Epidemiological approach. The interpretation of COI studies is directly influenced by the epidemiological perspective adopted and utilized by the study: incidence- or prevalencebased. The incidence-based approach measures the likely avoided costs if new cases are prevented (Larg \& Moss, 2011). Such studies sum the estimated lifetime costs that are attributable to cases that occur during the defined incident period, following which future costs are appropriately adjusted to their present day value (i.e., discounting; Mauskopf, 1998; Torgerson \& Raftery, 1999). The results derived from such studies can: (i) demonstrate how 
costs vary with disease duration (Larg \& Moss, 2011); (ii) inform planning interventions targeted at specific stages (Fiscella, Lee, Davis, \& Walt, 2009), and; (iii) can be used to inform the calculation of baseline costs for cost-effectiveness studies for interventions (Finkelsten \& Corso, 2003; Goldstein, Reznik, Lapsley \& Cass, 1986).

Prevalence-based approaches, in contrast, measure the actual impact of existing cases compared with a hypothetical alternative case prevalence (Larg \& Moss, 2011). Such studies measure disease-attributable costs that occur concurrently with prevalent cases over a specific time period (usually one year; Larg \& Moss, 2011). This approach is generally considered the most appropriate for assessing the total current economic burden of a health problem (WHO, 2009) as these studies usually include a cross-section of cases, thus capturing the costs at varying stages of disease (Mauskopf, 1998). However, this crosssection of individuals may also include cases that may not be amenable to intervention. Consequently, estimates derived using such an epidemiological approach is generally viewed as less reliable for measuring the potential savings from preventative interventions (WHO, 2009).

Cost Components. The economic burden of a given disease or health problem is estimated by accounting for the costs typically associated with resource consumption, productivity losses, and other 'intangible' burdens within a specified group. COI studies can comprise of direct, indirect or intangible costs (Dagenais, Caro, \& Haldeman, 2008; Luppa, Heinrich, Angermeyer, König, \& Riedel-Heller, 2007; Molinier et al., 2008). Direct costs refer to those that, at least in principle, involve a monetary exchange; and can include medical (e.g., hospital admissions, physician fees, and the cost of medication) and non-medical costs (e.g., insurance, litigation, or travel expenses; Dagenais et al., 2008; Luppa et al., 2007). Typically, direct medical costs are the easiest to estimate; and, consequently, the most commonly accounted for in many studies. This is likely due to the fact that records are kept of such transactions. In contrast, evidence of non-medical costs is comparatively less 
well documented or readily available making such costs more difficult to estimate (Dagenais et al., 2008; Luppa et al., 2007).

Indirect costs ascribe an economic value to those costs that do not have a clear monetary transfer (Dagenais et al., 2008), and usually relate to productivity losses.

Examples include the economic implications associated with sickness absence, turnover, and presenteeism to name a few (e.g., Béjean \& Sultan-Taïeb, 2005; McTernan, Dollard, \& LaMontagne, 2013). Within COI studies it is highly recommended that non-work related productivity losses should also be accounted for in derived cost estimates (e.g., housework, voluntary work, and other unpaid productivity work; Larg \& Moss, 2011); albeit this is not common practice (Molinier et al., 2008). In general, indirect costs are more difficult to quantify than direct costs, especially in relation to presenteeism (Dagenais et al., 2008). It may be for this reason, therefore, why many $\mathrm{COI}$ studies do not include or include only a minimal number of indirect costs in their respective calculations.

Several methods are commonly used to estimate the economic value to these indirect productivity losses, including: the human capital method; the friction cost method; the loss of potential output, and; the costs of life years lost (see Table 1; Dagenais et al., 2008; Hansen, 1993; Meltzer, 1997). These methods often use salary as a proxy for productivity which is then multiplied with the period of time where productivity loss occurs (Dagenais et al., 2008; Jo, 2014). The difference between methods, however, lies in the duration of time a person is considered unproductive. It is important to highlight that considerable academic debate exists in regards to which calculation approach is empirically and methodologically superior (e.g., Johannesson \& Karlsson, 1997). It is beyond the scope of this article to provide a meaningful summary of this academic debate; however, the interested reader is encouraged to read the following articles for a more detailed discussion (Hutubessy, van Tulder, Vondeling, \& Bouter, 1999; Johannesson \& Karlsson, 1997; Meltzer, 1997; van den Hout, 2010). 
[insert Table 1 here]

Intangible costs reflect the financial value prescribed to the pain and suffering, and the reduced quality of life experienced by the afflicted individual or group of individuals (Luppa et al., 2007). One approach to quantifying intangible costs is through willingness-topay (Gafni, 1991). Here, intangible costs are reflected in the financial value people would pay to avoid different levels of reduced quality of life brought upon by the disease. Due to the difficulty in accurately quantifying these experiences, intangible costs are seldom included in COI studies; although, their empirical importance in allowing valid and reliable cost estimates is strongly acknowledged within economic and public health fields respectively (HSE, 2011; Larg \& Moss, 2011).

\section{Aim of the Current Study}

The central objective of the systematic review was to collate, review and synthesize evidence-based economic estimations of the cost of work-related stress in relation to societal-level outcomes. More specifically, the systematic review aimed to: (i) describe the identified studies; (ii) classify and categorize the identified COI studies according to their main objectives and their methodological approach; (iii) provide a critical review on the methodology within COI studies; and (iv) to draw key conclusions for future research and consider implications for the field of OHP.

\section{Method}

A scoping review of the literature was conducted prior to the commencement of the study. The results informed the development of the research protocol, which was agreed upon by the entire research team. The systematic review was informed by the Preferred Reporting Items for Systematic Reviews and Meta-Analyses (PRISMA; Moher, Liberati, Tetzlaff, Altman \& The PRISMA Group, 2009) guidelines. 


\section{Search Strategy}

The databases searched were: ingentaconnect; EBSCO (Academic Search Premier, Business Source Premier, PsychArticles, Psychlnfo); JSTOR; Science Direct; and Web of Knowledge (Medline, Web of Science). Databases were searched on March $18^{\text {th }}, 2014$, and the inclusion period encompassed the start of the database until December $31^{\text {st }}, 2013$. To examine the grey literature, Google and Google Scholar were searched. Root search terms (with 14 associated free text variants) were identified in relation to two conceptual dimensions: cost ("financial cost", "economic cost", "evaluation cost", "cost-of-illness", "health cost", "productivity cost") and work-related stress ("effort-reward", "occupational stress", "job stress", "work stress", "work-related stress", "job strain", “isostrain", “iso-strain"). Additional articles and research reports were identified by: reviewing websites of NGOs (e.g., WHO), governmental departments (e.g., Department of Health), and non-departmental public bodies (e.g., UK Health and Safety Executive); examining references cited in identified papers, and; contacting subject matter experts. All titles and abstracts identified through the search strategy were examined, and relevant articles obtained for assessment. A follow up search of the literature was conducted in July 2016 . The aim of this search was to identify and consider any new articles published during the period between the original search of the literature and the point of publication. Only one additional study was identified.

Articles were required to meet four inclusion criteria: (i) be a COI study with a documented methodology; (ii) examine costs associated with work-related stress; (iii) be costed at a societal or national level (e.g., costs borne by a national health insurance/ service, economy, or government), and; (iv) be published in English, French, or German. No restrictions were placed on the approach or methodologies used to obtain the financial figure quoted. 


\section{Data Extraction and Synthesis}

A data extraction form was developed to standardize the extraction and synthesis process. This was peer-reviewed and piloted, with received feedback integrated into its further development. The finalized form extracted information relating to the study's background methodology, population, costs and sub-costs; and also included a study quality assessment checklist used to assess and compare the utilized methodologies. The checklist is based upon the ten-item health economic quality checklist (Drummond et al., 2005), which has been adapted for use in COI studies (Molinier et al., 2008; Te Ao, 2014).This adapted quality checklist has been used by several previous systematic reviews of COI studies examining Alzheimer's disease (Costa et al., 2012), opiate dependence (Doran, 2008), prostate cancer (Molinier et al., 2008), and traumatic brain injury (Te Au, 2014).

\section{Quality Checklist: Criteria and Scoring}

Each study was evaluated against ten criteria outlined in the quality assessment checklist (see Appendix I). These criteria critically examined the following methodological and conceptual domains: (i) specification of the utilized definition of work-related stress and theoretical grounding of the study; (ii) descriptive clarity of epidemiological sources used; (iii) detail in the disaggregation of total costs into appropriate sub-costs; (iv) transparency in the utilized activity data (i.e., the data linking epidemiological statistics [prevalence or incidence statistics] with an appropriate health or work outcome); (v) outlining and critically evaluating the nature all cost values used; (vi) identification of unit costs and consideration of their given value; (vii) provision of methodological detail of study parameters; (viii) the use of discounting (where appropriate); (viiii) the use of sensitivity analysis; and (x) presenting the results of the study consistently in relation to the utilized methodology.

Discounting refers to the adjustment of costs to reflect future costs having less of a value than present day costs (Mauskopf, 1998). This analytical procedure should be conducted where costs extend over a one year period. Discounting makes current costs 
and benefits worth more than those occurring in the future. This is as there is an opportunity cost to spending money now and a desire to enjoy benefits now rather than in the future (Torgerson \& Raftery, 1999). The economic models derived by COI studies are complex; and, consequently, contain many uncertainties and unknowns. Sensitivity analysis permits testing the robustness of the results by varying in range key variables (e.g. prevalence, unit costs, etc.; Costa et al., 2012).

In order to comparatively evaluate the studies, and attempt to rank them accordingly, a scoring system was devised. The scoring and ranking system is an adapted version to that used by Doran $(2008 ; 2013)$. A score was given in relation to each specified criteria (0 $=$ criterion not met; 1 = partially met; 2 = fully met). The score for each criterion were summed to provide a composite score for each study. A method of weighting was not used in relation to the ten criteria as such an approach has not been used or validated in previous $\mathrm{COI}$ reviews. Studies were categorized based by their yielded composite score: good (aggregated scores between 16 and 20), average (8 to 15), or poor quality (1 to 7; Doran, 2008). Each included study was independently rated by two reviewers; and differences discussed until consensus was obtained. No studies were excluded based on quality as it allowed for an examination of the diverse range of studies examining workrelated stress and their respective empirical and methodological quality.

\section{Review Process}

The search strategy identified 188 potentially relevant papers: 172 articles from the database searches and a further 16 from the non-database searches (see Figure 1). The review of identified articles was conducted in a two-stage process: (i) a title and abstract review; (ii) and, subsequently, a full-text review. In the first stage, one reviewer $\left(\mathrm{X}_{1}\right)$ assessed the identified titles and abstracts against two criteria: (i) the article must be a COI study, and (ii) it must examine work-related stress. After the removal of duplicates $(n=20)$, the application of these parameters resulted in the exclusion of 121 articles at this stage of the review, including: 73 articles that did not meet one of the two specified criteria, and a 
further 48 that failed to meet both criteria. To assess the consistency of the study selection process, a random selection of $20 \%$ of article abstracts $(n=38)$ were reviewed independently by two separate reviewers each $\left(X_{2}\right.$ and $\left.X_{3}\right)$. Both were blind to the first reviewer's decision. The observed Cohen's kappa statistics indicated moderate agreement (McHugh, 2012): $k$ $=.76$ and .71 , respectively. Disagreements were resolved through discussion and consensus among the research team. In total, 47 articles were short-listed and reviewed in the second stage of the review process by one reviewer $\left(X_{1}\right)$. All four specified inclusion criteria were applied at this stage. A total of 32 articles were excluded: two could not be retrieved, and 30 did not meet one or more of the set inclusion criteria. Subsequently, a random selection of $20 \%$ of the 46 articles was independently reviewed by $X_{2}$ and $X_{3}$ against the inclusion criteria. Interrater agreement was observably strong: $k=1$ and .83. In total, 15 articles were included in the review.

[insert Figure 1]

\section{Results}

The majority of the articles reviewed were from Western Europe (Denmark, $n=1^{3}$; France, $n=3^{4-6}$; Sweden, $n=1^{7}$; Switzerland $=1^{10}$; and, the United Kingdom, $n=3^{11-13}$ ) with one multinational study examining data from across the EU-15 member states ${ }^{14}$. The remaining five studies derived from: Australia $\left(n=3^{1,2,9}\right)$, Canada $\left(n=1^{15}\right)$, and the United States ${ }^{8}$. A descriptive summary of the reviewed articles is presented in Table 2. The publication year of retrieved articles ranged from 1996 to 2016, with the vast majority published after 2005 $(n=12 ; 80 \%)$. The epidemiological data used to inform the utilized prevalence or incidence statistics was also found to range substantially across studies (from 1991/1992 to 2011), with the majority of the articles using data collected between 2000 and $2009(n=10)$. In order to classify and categorize the identified COI studies, the included studies are presented according to the approach used: top-down $(n=8)$, bottom-up $(n=4)$, or deductive $(n=4)$. 


\section{Standardization of Cost Figures}

The estimated annual costs stated by each study are presented in Table 3. To allow for basic comparisons, country specific consumer price indexes were used to inflate total cost figures to December $31^{\text {st }}, 2014$, and then converted to US Dollars using purchase power parities (World Bank, 2015a). Using the most recent data available from the World Bank (2015b), the average cost per worker was calculated by dividing the total cost with the size of the country's 2014 national labor force. All annual costs, unless otherwise specified, are presented in 2014 valued US dollars.

[insert Table 3]

[insert Table 4]

\section{Quality Assessment of Included Studies}

Table 4 describes the ten COI quality assessment criteria and maps each study against it. In general, the reviewed studies met the vast majority of the set quality criteria, with six studies classed as good ${ }^{2-5,8-9}$, seven average ${ }^{1,6-7,10-12,14}$, and two poor ${ }^{13,15}$. None of the studies fully met all of the set quality criteria; albeit two studies partially met all ten. The majority of reviewed COI studies were judged as providing a satisfactory account of their utilized methodology and epidemiological source of data. In addition, a common analytical feature across many of the reviewed studies was discounting and sensitivity analysis. The quality assessment criteria that were, comparatively, less commonly met, included: outlining a definition of work-related stress; clearly describing how costs were disaggregated; and providing a clear account of the source(s) used to derive utilized cost estimates.

\section{Top-down Studies $(\mathbf{n}=8)$}

Study aims and characteristics. The aims of each individual study are briefly described in Table 2. Five national contexts were examined: Australia ${ }^{1,2}$, Denmark ${ }^{3}$, France ${ }^{4-}$ 
${ }^{6}$, Sweden ${ }^{7}$, and the United States ${ }^{8}$. The primary objective of seven studies was to examine the financial cost of job strain (defined as high demands and low control) and associated illness and ailments. Five of these seven studies focused on specific job strain related illnesses, including: depression and mental disorders ${ }^{1,2,4-6}$, cardiovascular disease ${ }^{4-6}$, and musculoskeletal disorders ${ }^{4,6}$. The remaining two studies examined job strain specifically. The utilized prevalence statistics by these studies ranged between $9 \%$ and $27.3 \%$, and were obtained using epidemiological data from national and regional epidemiological surveys collected between 1991 and 2010. The studies most commonly attempted to calculate the cost of job strain drawing on data obtained from the surveys collected within a year of the estimations. However, on two occasions the prevalence data was collected from two ${ }^{6-7}$ years earlier. In another instance, the cost of job strain in Denmark for 2005 was based on the Danish Health Interview Survey conducted five year earlier (Juel, Sorensen, \& BronnumHansen, 2008). The aim of the eighth study was to examine the financial costs associated with ten specified work stressors: being unemployed; having no health insurance; shift work; long work hours; job insecurity; work-family conflict; low job control; high job demands; low social support; and low organizational justice. Prevalence data were drawn from the 2002, 2006 and 2010 US General Social Survey, and the 2011 Current Population Survey. Within this category of studies, five studies were rated 'good'2-5,8 with the remaining ${ }^{1,6,7}$ rated 'average'.

Calculation technique and cost components. Seven ${ }^{1,3-8}$ of the eight studies accounted for one of several healthcare-related direct cost components, with medical care the direct cost component most frequently estimated. Other direct cost components accounted for, included: antidepressant medication; the use of mental health and primary care services; and, ambulatory care. None of studies reviewed accounted for non-healthcare related direct costs or intangible costs in their economic estimates.

Only one study ${ }^{8}$ did not estimate indirect costs in their economic model. Among the remaining seven studies, the most common indirect cost component estimated was 
sickness absence $(n=7)$. The friction cost method was used by the majority of studies to estimates this indirect cost $(n=6)$; whereby the number of sick days observed was multiplied with either daily GDP per capita ${ }^{4-6}$ or wage ${ }^{1-3,7}$. The remaining study ${ }^{3}$, however, used the human capital method to derive their estimate. The second indirect cost component most commonly accounted was early or premature death $(n=5)$. The majority of studies derived an estimated cost for early death by using the human capital method; followed by loss-ofpotential-output and cost-of-life-years-lost method. Other indirect costs examined were early retirement ${ }^{6,7}$, turnover $^{1}$, presenteeism ${ }^{2}$, and disability pension ${ }^{2}$; albeit, comparatively, less often.

Findings. The diverse aims and objectives, cost components, and definitions for work-related stress within this review are reflected in the wide range of work-related stress costs observed (see Table 2). At the national level, the cost of work-related stress ranged considerably: Australia (\$221.13 -\$580.32 million; cost per worker: $\$ 17.79$ to $\$ 46.68)$, Denmark ( $\$ 379$ million to $\$ 2.27$ billion; $\$ 130.07$ to $\$ 777.26$ ), France ( $\$ 1.83$ to $\$ 4.36$ billion; $\$ 60.95$ to $\$ 145.03$ ); Sweden (\$703.12 million; $\$ 136.71$ per worker); and the United States (\$187 billion; \$1211.84).

Figure 2 illustrates the proportion of the total cost of work-related stress accounted for by medical (direct) and production-related (indirect) costs mapped across identified studies and calculation techniques. Only five ${ }^{3-7}$ of the eight studies provided the necessary information to examine the proportion of costs. In general, production-related costs comprised the largest proportion of the estimated total costs, constituting approximately $70 \%$ to $90 \%$. Conversely, the remaining $10 \%$ to $30 \%$ of the estimated costs were borne by the healthcare system and associated medical costs. These cost estimates are directly influenced by the calculation technique used, and can be attributed to the length of time in which loss of production is considered to occur. For example, in Denmark ${ }^{3}$ a smaller estimated loss is observed when production loss is restricted to the first three months of leaving the labor market (friction cost method; \$374 million), than when it encompasses the 
duration until expected retirement age (human capital method; $\$ 2.24$ billion). Similarly, in France $^{4}$, the shorter timeframe of the human capital method yielded a lower cost $(€ 753$ million) in comparison to the cost-of-life-years-lost method (€954 million).

\section{Bottom-up approaches $(n=4)$}

Study aims and characteristics. The brief aims of each bottom-up study are presented in Table 2, with one study ${ }^{12}$ limiting their scope to costs arising exclusively from sickness absence. Within this category of studies, one was rated $\operatorname{good}^{9}$, with the remaining ${ }^{10-}$ 12 rated as average. A wider variety of definitions of work-related stress are used here compared to top-down approaches. Two studies ${ }^{9,10}$ examined the degree of self-reported perceived stress within the given population; while the remaining two studies ${ }^{11,12}$ defined their study by examining 'stress, depression and anxiety' inclusively. Three of the studies drew upon national surveys and incidence-based statistics examining the frequency of workrelated stress cases $^{9,11}$ and the number of working days lost ${ }^{12}$. The data used to inform the utilized statistics derived from national-level surveys, all of which collected data in the last 10 years $\left(2005 / 2006^{12} ; 2008 / 2011^{11} ; 2009 / 2010^{10}\right)$ and within a year of the year being costed by the COI analysis. The fourth ${ }^{10}$ study, set in 1999, obtained their prevalence statistics from a survey using their own research sample where data was collected in $1998^{12}$. Three national contexts were examined by those studies categorized as using a bottom-up approach: Australia $^{9}$, Switzerland ${ }^{10}$ and the United Kingdom ${ }^{11,12}$.

Calculation technique and cost components. Three of the bottom-up studies calculated the cost of work-related stress ${ }^{9-11}$ or work-related ill-health ${ }^{10}$ before multiplying with the number of persons with work-related stress. The fourth, by $\mathrm{SCMH}^{12}(2007)$, multiplied the number of days due to 'stress, depression and anxiety' with the estimated average cost per day incurred due to production loss. In general, a wider range of costs are included within bottom-up studies compared to the top-down studies. This is a result of the $\mathrm{COI}$ analyses conducted by the national health and safety agencies of Australia ${ }^{9}$ and the United Kingdom ${ }^{11}$ being more sensitive and including a broader range of cost components in 
order to obtain a more accurate national picture of the cost of work-related ill-health. In addition to the direct healthcare costs, both these studies examined direct non-healthcare costs including: administration, funeral, home, legal, travel and others costs (Table 3). These estimates were informed by information derived from various national databases. In contrast, Ramaciotti and Perriard ${ }^{10}$ (2003) used financial information relating to medical services and self-medication provided by 150 surveyed individuals. This was used to derive an estimate for average cost per case of work-related stress. This aggregated figure was than extrapolated to the national sample.

The majority of indirect costs (specifically, turnover ${ }^{9,11}$, sickness absence ${ }^{9,10,12}$, and work reorganization ${ }^{11}$ ) were estimated using the friction cost method to derive an estimated cost; albeit the cost of early retirement was estimated using the human capital method by the SafeWork Australia ${ }^{9}$ study. Intangible costs (i.e., non-financial human costs) were accounted for in only one study ${ }^{11}$ (both within this category of studies and across all reviewed studies) conducted by the UK Health and Safety Executive (HSE). This cost component was based on information derived from a representative sample on their reported willingness to pay to avoid reductions in quality of life resulting from illness or death.

Findings. Across the studies using a bottom-up approach the total cost of workrelated stress was observed to cost $\$ 3.33$ billion in Switzerland ${ }^{10}$ (cost per worker $\$ 701.14$ ), $\$ 3.98$ billion in Australia ${ }^{9}$ ( $\$ 320.14$ per worker), and $\$ 5.42$ billion in the United Kingdom ${ }^{11}$ (\$164.58 per worker). The COI study that exclusively estimated sickness-related absence within the United Kingdom ${ }^{12}$ observed a cost of $\$ 2.18$ billion ( $\$ 66.35$ per worker).

Limited information was provided among the four bottom-down studies regarding the observed proportion of cost components associated with the total estimated costs of workrelated stress. Two studies discuss the proportion of costs associated with the estimated costs of work-related ill health; rather than work-related stress. The study conducted by the HSE observed the non-financial human (i.e., intangible) cost constituted $56 \%$ of the total costs of work-related ill-health; and SafeWork Australia ${ }^{9}$ found that indirect costs associated 
with production loss made-up $86 \%$ of the cost of work-related ill-health. However, Ramaciotti and Perriard (2003) ${ }^{10}$ found sickness absences (59.9\%) to account for the majority of the estimated cost of work-related stress, followed by medical services $(31.53 \%)$ and self-medication (8.57\%).

\section{Deductive approaches $(n=3)$}

Study aims and characteristics. Within this category of studies, two studies were rated as poor ${ }^{13,15}$ and the third ${ }^{14}$ of average quality. Table 2 presents the brief aims of each individual study. These studies examined Canada ${ }^{15}$, the United Kingdom ${ }^{13}$, and the EU15 14 . Two studies defined work-related stress as job strain ${ }^{14,15}$, and the third examined 'stress, anxiety and depression' inclusively ${ }^{13}$. Deductive approaches first obtain the estimated overall cost of work-related ill-health. Then, a percentage that represents the proportion of costs that are attributable to work-related stress is applied to the overall cost of work-related ill-health. The first study ${ }^{13}$ applied a 35\% figure drawn from the UK Labour Force Survey (data collected in 2002). The remaining two studies ${ }^{14,15}$ used estimates derived from the same Swedish study (Levi \& Lunde-Jensen, 1996), which estimated that $10-25 \%$ of workrelated illness costs are associated with work-related stress. Neither study, however, explained how these figures from Sweden were estimated. The first of these two studies ${ }^{15}$ used both the upper and lower estimate to derive their calculations for the UK context for 2008. In contrast, the second study did not make clear why only the lower more conservative estimate of $10 \%{ }^{14}$ was used to yield an estimate for the EU-15 for 1999 .

Calculation technique and cost components. The cost components used to inform the utilized calculations relate directly to those used to estimate the overall cost of workrelated illness. Two studies ${ }^{13,14}$ did not outline the accounted for cost components or considered sub-costs in relation to the utilized figure of work-related illness. The last study ${ }^{15}$ specified the cost components considered in the calculation of the total cost of work-related illness, including: cost of mental health care, social service, productivity loss, and other costs. 
Findings. At the national level, the estimated cost of work-related stress in Canada ${ }^{15}$ ranged from $\$ 2.59$ to upwards of $\$ 9.59$ billion, with the estimated cost per Canadian worker ${ }^{15}$ ranging between $\$ 131.31$ and $\$ 486.33$. In the $\mathrm{UK}^{13}$ the cost of work-related stress was estimated to range from $\$ 13.13$ to $\$ 23.63$ billion, approximately $\$ 398.10$ to $\$ 716.58$ per British worker. The cost of work-related stress within the EU-15 14 for 2014 was estimated to be $€ 26.47$ billion. As purchasing power parity for the combined EU-15 14 was not available, the cost per worker could not be calculated for this study. The proportional split between production, medical and other costs are not available as these are calculated at the level of the cost of work-related ill-health, not of work-related stress.

\section{Discussion}

The aim of the current study was to collate, summarize and comparatively evaluate COI studies that examined the total cost of work-related stress to society (as expressed in US \$). The review identified a modest number of such studies. Together these studies were drawn from a limited number of national contexts. Their derived economic cost estimates, when comparatively assessed, demonstrated a considerable range in relation to this social and occupational phenomenon. The total estimated cost of work-related stress was observed to range from $\$ 221.3$ million to upwards of $\$ 187$ billion (presented figures inflated to 2014 US dollars) across identified studies; with the projected cost per working person ranging from $\$ 17.79$ to upwards of $\$ 1,211.84$. This surprisingly broad range of estimates was found across several levels of comparative analysis: internationally, nationally, and by methodological approach.

The broad range of cost estimates observed by the current review does not yield a 'clean and simple' conclusive, or indeed definitive, statement on the nature and scale of the 'true' cost of work-related stress to society. Moreover, this review raises more questions than it provides answers to. The current discussion aims to provide an exploratory discussion of the possible reasons underpinning the observed complexity and diversity of current estimates of the cost of work-related stress to society. It tentatively suggests how 
such knowledge might frame our interpretation of such figures. Reflecting on such issues of complexity and diversity the authors feel that this paper adds value to the development of the OHP discipline. Arguably, it starts to provide a conceptual and methodological framework within which to understand and critique relevant studies and their associated cost estimates.

\section{The Cost of Work-related Stress: Missing the Global Picture?}

A central focus on the current study was to gain an international perspective on the burden of work-related stress to society. However, the vast majority of studies examined the European national context (in particular, France and the UK). Beyond Europe, just three countries were examined: Australia, the United States and Canada. Therefore, examining the costs of work-related stress to society from a global perspective is, at this point, difficult due to the relatively restricted number of national contexts explored and respective costs estimated. As such, this represents a significant gap in the literature. Further research is needed to examine the nature and magnitude of this issue in a more diverse sample of countries; and, in particular, within developing and newly industrialized economies. Understanding the economic impact of a wider range of work-related psychosocial health issues is vital to understanding the economic impact to society caused by poor psychosocial working conditions; beyond those costs just associated with work-related stress. These estimates are vital to supporting a business case for psychosocial risk management, and, in turn, encouraging preventive action at policy level.

\section{Defining and Measuring Work-related Stress}

The discrepancy across observed cost estimates may be partly explained by the ways in which work-related stress has been defined, and, in turn, measured across reviewed studies (e.g., job strain; work stress; stress, depression and anxiety, etc.). Some quantify this phenomenon by the degree of exposure to adverse psychosocial working conditions, whilst others used data derived from self-report declarations of the presence or absence of the condition stress. Houdmont, Cox and Griffiths (2010) observed a 
considerable variety in case definitions of work-related stress used among 18 nationally representative workforce surveys of British workers. Such definitions were found to vary in terms of their theoretical basis, structure and content. Each was associated with a unique, and comparatively varied, range of prevalence rates. Consequently, such study design considerations will have a direct impact on the level of measurement error observed within the utilized epidemiological statistics used to derive such economic estimates. Furthermore, it is important to highlight that in many of the studies, analyzed for this paper, the time discrepancy between the collection of data and publication of the study is substantive. Some such periods were as large as 12 years (Shain et al., 2008) and others as small as one year (SCMH, 2007). Therefore, it is important that cost estimates derived must be interpreted critically with reference to their respective methodological and historical context.

\section{Comprehensive Measurement: Cost Categories and Cost Components}

A consideration of the cost components included (and, in turn, not included) by the reviewed COI studies yields an important interpretative lens in which to consider the range of cost estimates observed. The established view, and considered best practice, is that cost components derived from all three cost categories should be included in economic models: direct, indirect and intangible costs (Dagenais e al., 2008; Molinier et al., 2008). By doing so, a comprehensive and, arguably, more accurate estimate of the financial burden posed by work-related stress might be achieved. Among reviewed studies, direct and indirect cost components were included in the majority of economic models developed. There was an overall tendency to account for medical, sickness absence and early retirement costs. However, only one study included intangible costs within their economic model (HSE, 2013).

In relation to direct costs, most of the costs components included were related to the direct costs associated with healthcare; in particular, those related to diagnosis and treatment. Very few studies, however, accounted for the consumption of non-healthcare resources like transportation, legal costs, household expenditures, relocating, property 
losses, and informal care of any kind. In relation to indirect costs (or productivity-related costs), two particular costs components were typically absent in many of the economic models developed: costs associated with turnover and presenteeism. Preliminary evidence suggests that such cost components may carry a sizable monetary value. As a result, the omission of such costs may result in a shortfall in the final cost estimates. For example, presenteeism has been estimated to cost 1.5 to 10 times more than the sickness absence (Goetzel et al., 2004; McTernan et al., 2013; SCMH, 2007).

The cost components associated with intangible costs are seldom included in economic models within this field. This failure is a noted methodological limitation that has defined many COI studies in other areas of health research (Larg \& Moss, 2011). Preliminary research, derived from allied health literature, observe that intangible costs constitute a significant, if not overwhelming, proportion of economic estimates. For example, $67 \%$ of the total cost of underage drinking was related to intangible costs (Miller et al., 2006), as was between $45 \%$ and $65 \%$ of the cost of coronary heart disease (Scott et al., 1993), and $56 \%$ of the total cost of work-related ill-health (HSE, 2013). Arguably, the omission of intangible and other important indirect costs within cost estimates of workrelated stress are a sizable conceptual omission; but also potentially a significant (and potentially costly) exclusion from derived economic estimates.

Much of the conceptual focus and definition of intangible costs within the health economics literature has almost exclusively defined this cost category in relation to indices of quality of life, such as: grief, suffering, pain and loss (HSE, 2011; Larg \& Moss, 2011). The authors would argue that the concept of intangible costs should be extended to consider indices related to the quality of working life, such as: job satisfaction, work engagement, fulfilling and meaningful work, and so on. The inclusion of such additional intangible cost components is of critical importance in deriving a comprehensive and holistic economic model of the total cost of work-related stress. In turn, it should ensure a cost figure more representative of the financial burden posed by this phenomenon. 
In summary, a relatively narrow range of cost components were accounted for by the studies included in this review. The authors conclude that the available cost estimates yield no more than a tentative 'snap-shot' of the likely financial burden of work-related stress to society. While such 'snap-shots' may have some theoretical and practical value, they can provide only an approximation of the financial burden posed by work-related stress. The importance of critically reflecting on the nature and monetary impact of cost components, excluded within many economic models, is highlighted as a key area of consideration by the current review. Their importance lies not only in terms of the likely direct implication in terms of cost estimates, but also in terms of the design of future COI studies within this field. Particular concern is expressed here in relation to indirect costs and, particularly, those related to quality of working life. In some cases such cost components constitute a sizable proportion of the estimated total cost; and, therefore, their exclusion may suggest that the reviewed cost estimates are at best conservative and at worst a gross underestimation.

\section{Methodological Limitations of the Current Systematic Review}

Two methodological limitations should be considered in relation to this review. Firstly, by restricting the search strategy to articles in English, German and French, potentially relevant studies in Dutch (e.g., Blatter, Houtman, van den Bossche, Kraan \& van den Heuvel, 2005; Konigsveld et al., 2003) and Spanish (e.g., UGT, 2013) were excluded. Therefore, the inclusion of wider spectrum of languages might have revealed a larger sample of articles and from a more diverse set of national contexts. Secondly, the adjustments made to obtain the average cost of work-related stress per economically active person only permits a crude form of comparison between studies; and should, be interpreted with a healthy degree of caution.

\section{Conclusion}

"The truth is rarely pure and never simple" Oscar Wilde (1986; 1.1.87). 
The review concludes that examining the costs of work-related stress to society from an international perspective is, at this point in time, difficult. This is due to the restricted number of national contexts able to be explored, and to the observed diversity across studies in terms of their conceptual and methodological approaches. What is certain is that cost estimates for work-related stress should not be taken at face value. Critical understanding of their context and the methodology used is paramount. Such cost estimates only provide a context-dependent 'snap-shot' of the estimated financial burden posed by work-related stress and are not without their methodological limitation. These estimates do, however, act as an important catalyst in encouraging necessary debate in OHP and further afield in research, policy and practice. Such cost figures can act as important 'conversational guesstimates' highlighting the respective burden posed by workrelated stress to society at large. While the search for the 'true' cost of work-related stress remains an on-going question, the methodological aspects and considerations of this quest for the 'holy grail' is of value in the dialogue it stimulates.

\section{References}

American Institute of Stress (n.d.). Work Stress: Job Stress is Costly. Retrieved from: http://www.stress.org/workplace-stress/

${ }^{5}$ Béjean, S. \& Sultan-Taïeb, H. (2005). Modelling the economic burden of diseases imputable to stress at work. European Journal of Health Economics, 6(1), 16-23.

Blatter, B., Houtman, I., van den Bossche, S., Kraan, K., \& van den Heuvel, S., Gezondheidsschade en kosten als gevolg van RSI en psychosociale arbeidsbelasting in Nederland, TNO Report, 2005. Available at: http://docs.szw.nl/pdf/129/2006/129_2006_3_8656.pdf 
Bloom, D. E., Canning, D., \& Sevilla, J. (2001). The effect of health on economic growth: Theory and evidence. Cambridge, MA: National Bureau of Economic Research. NBER Working Paper \#8587.

Bonde, J. P. (2008). Psychosocial factors at work and risk of depression; A systematic review of the epidemiological evidence. Occupational and Environmental Medicine, 65(7), 438-445. doi: 10.1136/oem.2007.038430

${ }^{13}$ Chandola, T. (2010). Stress at work, The British Academy, London.

Cooper, N. J. (2000). Economic burden of rheumatoid arthritis: A systematic review. Rheumatology, 29, 28-33. doi: 10.1093/rheumatology/39.1.28

Costa, N., Derumeaux, H., Rapp, T., Garnault, V., Ferlicoq, L., Gillette, S., ... \& Molinier, L. (2012). Methodological considerations in cost of illness studies on Alzheimer disease. Health economics review, 2(1), 1-12.

Cox, T., Griffiths, A., \& Rial-Gonzalez, E. (2000). Research on work related stress. Luxembourg: Office for Official Publications of the European Communities.

Dagenais, S., Caro, J., \& Haldeman, S. (2008). A systematic review of low back pain cost of illness studies in the United States and internationally. The spine journal, 8(1), 8-20.

Doran, C. M. (2008). Economic evaluation of interventions to treat opiate dependence. Pharmacoeconomics, 26(5), 371-393.

Doran, C. M. (2013). The evidence on the costs and impacts on the economy and productivity due to mental ill health: a rapid review. Sax Institute and the Mental Health Commission of NSW, Haymarket, Australia.

Drummond, M. F., Sculpher, M. J., Torrance, G. W., O’Brien, B. J., \& Stoddart, G. L. (2005). Methods for the economic evaluation of health care programmes: Oxford University Press. New York.

Drummond, M. F., Stoddart, G. L., \& Torrance, G. W. (1987). Methods for the economic evaluation of health care programmes. Oxford: Oxford University Press. 
EU-OSHA — European Agency for Safety and Health at Work (2013). European opinion poll on occupational safety and health 2013. Retrieved at: https://osha.europa.eu/en/surveys-and-statistics-osh/european-opinion-pollssafetyand-health-work/european-opinion-poll-occupational-safety-and-health-2013 EU-OSHA - European Agency for Safety and Health at Work (2014). Calculating the cost of work-related stress and psychosocial risks. Publications Office of the European Union: Luxembourg. Available at: https://osha.europa.eu/en/tools-andpublications/publications/literature reviews/calculating-the-cost-of-work-relatedstress-and-psychosocial-risks

Eurofound - European Foundation for the Improvement of Living and Working Conditions (2012). Fifth European working conditions survey. Publications Office of the European Union: Luxembourg. Available at: http://www.eurofound.europa.eu/surveys/ewcs/2010/

${ }^{14}$ European Commission (2002). Guidance on work-related stress: Spice of life or kiss of death. Publications Office of the European Union: Luxembourg. Available at: https://osha.europa.eu/data/links/guidance-on-work-related-stress.

Finkelstein, E., \& Corso, P. (2003). Cost-of-illness analyses for policy making: a cautionary tale of use and misuse. Expert review of pharmacoeconomics \& outcomes research, 3(4), 367-369.

Fiscella, R. G., Lee, J., Davis, E. J., \& Walt, J. (2009). Cost of illness of glaucoma. Pharmacoeconomics, 27(3), 189-198.

Gafni, A. (1991). Willingness-to-pay as a measure of benefits: relevant questions in the context of public decision making about health care programs. Medical care, 29(12), 1246-1252.

Giga, S., Hoel, H., \& Lewis, D. (2008). The costs of workplace bullying: A report and review. Research Commissioned by the Dignity at Work Partnership. Available at: 
http://www.unitetheunion.org/resources/equalities_2011/equalities_-

_legacy_content/equalities_campaigns/dignity_at_work/downloads.aspx.

Goetzel, R. Z., Long, S. R., Ozminkowski, R. J., Hawkins, K., Wang, S., \& Lynch, W. (2004). Health, absence, disability, and presenteeism cost estimates of certain physical and mental health conditions affecting US employers. Journal of Occupational and Environmental Medicine, 46(4), 398-412.

Goh, J., Pfeffer, J., \& Zenios, S. A. (2016). The relationship between workplace stressors and mortality and health costs in the United States. Management Science.

Goldstein, G., Reznik, R., Lapsley, H., \& Cass, Y. (1986). Costing acute myocardial infarction in New South Wales, Australia, based on incidence rather than prevalence methods. Community health studies, 10(1), 31-38.

Hansen, S.M. Arbejdsmiljø og samfundsøkonomi-en metode til konsekvensberegning. Oslo: Nordic Council of Ministers; 1993 (NORD 1993:22 and working report 1993:556).

Hoel, H., Sparks, K., \& Cooper, C.L. (2001). The cost of violence/stress at work and the benefits of a violence/stress-free working environment. International Labour Organization (ILO): Geneva. Available at: http://www.ilo.org/safework/info/publications/WCMS_118190/lang--en/index.htm.

Houdmont, J., Cox, T., \& Griffiths, A. (2010). Work-related stress case definitions and prevalence rates in national surveys. Occupational Medicine, 60(8), 658-661.

${ }^{11} \mathrm{HSE}$ - Health and Safety Executive (2011). Costs to Britain of workplace fatalities and self-reported injuries and ill health, 2010/11 (data complemented through direct correspondence with the HSE). Crown Copyright: London.

Hutubessy, R. C., van Tulder, M. W., Vondeling, H., \& Bouter, L. M. (1999). Indirect costs of back pain in the Netherlands: a comparison of the human capital method with the friction cost method. Pain, 80(1), 201-207. 
Jo, C. (2014). Cost-of-illness studies: concepts, scopes, and methods. Clinical and molecular hepatology, 20(4), 327-337.KT

Johannesson, M., \& Karlsson, G. (1997). The friction cost method: a comment. Journal of health economics, 16(2), 249-255.

3Juel, K., Sorensen, J., \& Bronnum-Hansen, H. (2006). Risikofaktorer og folkesundhed $i$ Danmark. Statens Institut for Folkesundhed: Copenhagen.

Kivimäki, M., Head, J., Ferrie, J. E., Brunner, E., Marmot, M. G., Vahtera, J., \& Shipley, M. J. (2006). Why is evidence on job strain and coronary heart disease mixed? An illustration of measurement challenges in the Whitehall II Study. Psychosomatic Medicine, 68(3), 398-401.

Kivimäki, M., Leino-Arjas, P., Luukkonen, R., Riihimäki, H., Vahtera, J., \& Kirjonen, J. (2002). Work stress and risk of cardiovascular mortality: prospective cohort study of industrial employees. BMJ, 325(7369), 857. doi: http://dx.doi.org/10.1136/bmj.325.7369.857

Koningsveld, E.A.P., Zwinkels, W., Mossink, J.C.M., Thie, X., \& Abspoel, M. (2003). Maatschappelijke kosten van arbeidsomstandigheden van werknemers in 2001, Werkdocument 203. Ministry of Social Affairs and Employment: The Hague, 2003.

Kortum, E., Leka, S., \& Cox, T. (2010). Psychosocial risks and work-related stress in developing countries: health impact, priorities, barriers and solutions.International journal of occupational medicine and environmental health, 23(3), 225-238.

Koopmanschap, M. A. (1998). Cost-of-illness studies. Pharmacoeconomics, 14(2), 143-148. Kouvonen, A., Kivimäki, M., Virtanen, M., Pentti, J. \& Vahtera, J. (2005). Work stress, smoking status, and smoking intensity: an observational study of 46190 employees. Journal of Epidemiology \& Community Health, 59: 63-69. doi:10.1136/jech.2004.019752.

Kouvonen, A., Kivimäki, M., Elovainio, M., Väänänen, A., De Vogli, R., Heponiemi, T., Linna, A., ... Vahtera, J. (2008). Low organisational justice and heavy drinking: A 
prospective cohort study. Occupational and Environmental Medicine, 65(1), 44-50. doi: oem.2007.032755v1

Kuper, H., \& Marmot, M. (2003). Job strain, job demands, decision latitude, and risk of coronary heart disease within the Whitehall II study. Journal of Epidemiology \& Community Health, 57(2), 147-153. doi: 10.1136/jech.57.2.147

'LaMontagne, A.D., Sanderson, K., \& Cocker, F. (2010). Estimating the economic benefits of eliminating job strain as a risk factor for depression. VicHealth: Australia.

Langer, A. (2012). A framework for assessing Health Economic Evaluation (HEE) quality appraisal instruments. BMC health services research, 12(1), 1.

Larg, A., \& Moss, J. R. (2011). Cost-of-illness studies. Pharmacoeconomics, 29(8), 653-671.

Leigh, J. P. (2006). Expanding research on the economics of occupational health. Scandinavian Journal of Work, Environmental and Health, 32(1), 1-4. doi:10.5271/sjweh.969

Leka, S. \& Jain, A. (2010). Health impact of psychosocial hazards at work: An overview. World Health Organization: Geneva.

${ }^{7}$ Levi, L., \& Lunde-Jensen, P. (1996). A model for assessing the costs of stressors at national level. European Foundation for Living and Working Conditions: Dublin.

Lord, J., \& Ruiz, F. (2008). Presentation of economic information in NICE clinical guidelines: adaptation of the GRADE profile (HESG Spring 2008). National Institute for Health and Clinical, London.

Luppa, M., Heinrich, S., Angermeyer, M. C., König, H. H., \& Riedel-Heller, S. G. (2007). Costof-illness studies of depression: A systematic review, 98, 29-43. doi: http://dx.doi.org/10.1016/j.jad.2006.07.017

Mauskopf, J. (1998). Prevalence-based economic evaluation. Value in Health, 1(4), 251-259. 
McHugh, M. L. (2012). Interrater reliability: the kappa statistic. Biochemia medica, 22(3), 276282.

${ }^{2}$ McTernan, W. P., Dollard, M. F., \& LaMontagne, A. D. (2013). Depression in the workplace: An economic cost analysis of depression-related productivity loss attributable to job strain and bullying. Work \& Stress: An International Journal of Work, Health \& Organisations, 27(4), 321-338. doi: 10.1080/02678373.2013.846948

Meltzer, D. (1997). Accounting for future costs in medical cost-effectiveness analysis. Journal of health economics, 16(1), 33-64.

Miller, T. R., Levy, D. T., Spicer, R. S., \& Taylor, D. M. (2006). Societal costs of underage drinking. Journal of studies on alcohol, 67(4), 519-528.

Moher, D., Liberati, A., Tetzlaff, J., \& Altman, D. G. \&, The PRISMA Group (2009). Preferred reporting items for systematic Reviews and meta-analyses: The PRISMA Statement. PLoS Med 6(6): e1000097. doi:10.1371/journal.pmed1000097

Mogyorosy, Z., \& Smith, P. (2005). The main methodological issues in costing health care services: A literature review (No. 007). Centre for Health Economics: University of York.

Molinier, L., Bauvin, E., Combescure, C., Castelli, C., Rebillard, X., Soulié, M., ... \& Grosclaude, P. (2008). Methodological considerations in cost of prostate cancer studies: a systematic review. Value in Health, 11(5), 878-885.

Quentin, W., Riedel-Heller, S. G., Luppa, M., Rudolph, A., \& Konig, H. H. (2010). Cost ofillness studies of dementia: A systematic review focusing on stage dependency of costs. Acta Psychiatrica Scandinavia, 121(4), 243-259. doi: 10.1111/j.16000447.2009.01461.x

${ }^{10}$ Ramaciotti, D., \& Perriard, J. (2003). Die kosten des stresses in der Schweiz. Staatssekretariat für Wirtschaft. SECO: Bern. Available at: http://www.seco.admin.ch/dokumentation/publikation/00008/00022/01511/index.html. 
Rothfuss, J., Mau, W., Zeidler, H., \& Brenner, M. H. (1997). Socioeconomic evaluation of rheumatoid arthritis and osteoarthritis: A literature review. Seminars in Arthritis and Rheumatism, 26(5), 771-779.

Sacristán, J. A., Soto, J., \& Galende, I. (1993). Evaluation of pharmacoeconomic studies: utilization of a checklist. Annals of pharmacotherapy, 27(9), 1126-1133.

${ }^{9}$ SafeWork Australia (2012). The Cost of Work-related Injury and IIIness for Australia Employers, Workers and the Community: 2008-09. Safe Work Australia: Canberra.

Schuetz, R. (2013). Stressed at work? You might have a workers compensation claim. GP Solo, 2, 12.

${ }^{12} \mathrm{SCMH}$ - Sainsbury Centre for Mental Health (2007). Mental health at work: developing a business case, policy paper 8 . Available at: http://www.centreformentalhealth.org.uk/pdfs/mental_health_at_work.pdf.

Scott, W. G., White, H. D., \& Scott, H. M. (1993). Cost of coronary heart disease in New Zealand. The New Zealand medical journal, 106(962), 347-349.

${ }^{15}$ Shain, S. (2008). Stress at work, mental injury and the law in Canada: A discussion paper for the mental health commission of Canada. Available at: http://www.mentalhealthcommission.ca/SiteCollectionDocuments/Key_Documents/en /2009/Stress\%20at\%20Work\%20MHCC\%20V\%203\%20Feb\%202009.pdf.

Spurgeon, A., Harrington, J.M., \& Cooper, C.L. (1997). Health and safety problems associated with long working hours: A review of the current position. Occupational \& Environmental Medicine, 54(6), 367-375.

Stansfeld, S., \& Candy, B. (2006). Psychosocial work environment and mental health - A meta-analytic review. Scandinavian Journal of Work, Environment \& Health, 32(6), 443-462.

Sullivan, S. E., \& Bhagat, R. S. (1992). Organizational stress, job satisfaction and job performance: where do we go from here?. Journal of Management, 18(2), 353-374. 
Suzuki, S., Ohida, T., Kaneita, Y., Yokoyama, E., Miyake, T., Harano, S., Yagi, Y., Ibuka, E., Kaneko, A., Tsutsumi, T., \& Uchiyama, M. (2004). Mental health status, shift work, and occupational accidents among hospital nurses in Japan. Journal of Occupational Health, 46, 448-454.

Sultan-Taïeb, H., Chastang, J. F., Mansouri, M., \& Niedhammer, I. (2013). The annual costs of cardiovascular diseases and mental disorders attributable to job strain in France. BMC Public Health, 13, 748. doi: 10.1186/1471-2458-13-748.

Tarricone R. (2006). Cost-of-illness analysis: What room in health economics? Health Policy, 77, 61-63. doi: 10.1016/j.healthpol.2005.07.016

Torgerson, D. J., \& Raftery, J. (1999). Discounting. British Medical Journal,319(7214), 914.

Te Ao, B. J. (2014). Measuring the economic cost of traumatic brain injury (TBI) in New Zealand: a cost-of-illness study (Doctoral dissertation, Auckland University of Technology).

${ }^{6}$ Trontin, C., Lassagne, M., Boini, S.,\& Rinal, S. (2010). Le coût du stress professionnel en France en 2007. Institut National de Recherche et de Sécurité: Paris, 2010. Available at: http://amsndev.circum.net/iso_album/coutstressprofessionnel2007.pdf.

UGT - Unión General de Trabajadores (2013). Costes Socio-Económicos de los Riesgos Psicosociales. UGT-CEC. Available at:

http://www.ugt.es/saludlaboral/observatorio/publicaciones/new2013/GuiaCostes.pdf

Ungar, W. J., \& Santos, M. T. (2003). The Pediatric Quality Appraisal Questionnaire: an instrument for evaluation of the pediatric health economics literature. Value in Health, 6(5), 584-594.

Van den Hout, W. B. (2010). The value of productivity: human-capital versus friction-cost method. Annals of the rheumatic diseases, 69(Suppl 1), i89-i91. 
Virtanen, M., Ferrie, J.E., Gimeno, D., Vahtera, J., Elovainio, M., Singh-Manoux, A., Marmot, M.G., \& Kivimäki, M. (2009). Long working hours and sleep disturbances: The Whitehall II prospective cohort study. Sleep, 32(6), 737-45.

Walker, D. G., Wilson, R. F., Sharma, R., Bridges, J., Niessen, L., Bass, E. B., \& Frick, K. (2012). Best practices for conducting economic evaluations in health care: a systematic review of quality assessment tools.

Wilde, O. (1986). The Importance Of Being Earnest, And Other Plays. London: Penguin Books. Originally published as The Importance of Being Earnest, by Oscar Wilde, 1895.

WHO - World Health Organization. (2009). WHO guide to identifying the economic consequences of disease and injury. Available at: http://www.who.int/choice/publications/d_economic_impact_guide.pdf

World Bank (2015a). PPP conversion factor, GDP (LCU per international \$). Available at: http://data.worldbank.org/indicator/PA.NUS.PPP

World Bank (2015b). Labor force, total. Available at: http://data.worldbank.org/indicator/SL.TLF.TOTL.IN

Wordsworth, S., Ludbrook, A., Caskey, F., \& Macleod, A. (2005). Collecting unit cost data in multicentre studies. The European Journal of Health Economics, 6(1), 38-44.

\section{Appendix: Tables and Figures}

Table 1. Methods for estimating loss of productivity

Table 2. Overview of study aims and sample backgrounds

Table 3. Costs of work-related

Table 4. Quality assessment criteria rating of the fourteen studies 
Figure 1. The review process based on PRISMA flow diagram

Figure 2. Proportion of medical and production loss-related (sickness absence, premature death and premature workforce exit) costs 
Table 1: Methods for estimating loss of productivity

\begin{tabular}{|c|c|c|}
\hline Method & $\begin{array}{l}\text { Duration of Time Where Production } \\
\text { Loss Occurs }\end{array}$ & $\begin{array}{l}\text { Basic Formula for Productivity } \\
\text { Loss }\end{array}$ \\
\hline $\begin{array}{l}\text { Human } \\
\text { Capital }\end{array}$ & $\begin{array}{l}\text { Loss of productivity of a worker is the period of } \\
\text { time between when the worker exits the workforce } \\
\text { due to illness or premature death, and the time } \\
\text { they naturally would have exited the workforce } \\
\text { (i.e., retirement). }\end{array}$ & $\begin{array}{l}\text { (Mean retirement age - Age when worker } \\
\text { left workforce) X Annual salary }\end{array}$ \\
\hline Friction Cost & $\begin{array}{l}\text { Productivity is only affected in the period it takes } \\
\text { someone from the unemployed pool to replace the } \\
\text { performance of the worker. The longer it takes to } \\
\text { replace a worker, or the longer a worker is absent } \\
\text { from work, the higher the cost incurred. }\end{array}$ & $\begin{array}{l}\text { (Time it takes to recruit and train a } \\
\text { replacement) } X \text { annual salary }\end{array}$ \\
\hline $\begin{array}{l}\text { Loss-of- } \\
\text { Potential- } \\
\text { Output } \\
\text { (Hansen, } \\
\text { 1993) }\end{array}$ & $\begin{array}{l}\text { Like the human capital method, the period of } \\
\text { production loss used by loss-of-potential-output } \\
\text { method encompasses the time from early } \\
\text { retirement or death, until the expected retirement } \\
\text { age. However, this method involves an implicit } \\
\text { weighting so that long-term absence results in a } \\
\text { bigger loss of potential output. This means that } \\
\text { inability to work among young workers is weighed } \\
\text { more heavily than among elderly workers }\end{array}$ & $\begin{array}{l}\text { (Mean retirement age - Age when worker } \\
\text { left workforce) X Annual salary X } \\
\text { Weighting value }\end{array}$ \\
\hline $\begin{array}{l}\text { Cost-of-Life- } \\
\text { Years-Lost } \\
\text { (Meltzer, } \\
\text { 1997) }\end{array}$ & $\begin{array}{l}\text { Individuals make productive contributions to } \\
\text { society even in retirement. Therefore, the period of } \\
\text { an individual's production loss ranges from when } \\
\text { they exited to the workforce until their mean life } \\
\text { expectancy. }\end{array}$ & $\begin{array}{l}\text { (Mean life expectancy - Age when } \\
\text { worker left workforce) } X \text { annual salary }\end{array}$ \\
\hline
\end{tabular}


Table 2: Overview of study aims and sample backgrounds

\begin{tabular}{|c|c|c|c|c|c|c|}
\hline Study & Country & Definition & Brief Aim & $\begin{array}{l}\text { Survey (Year } \\
\text { collected) }\end{array}$ & $\begin{array}{l}\text { Work-related Stress } \\
\text { Incidence/ Prevalence }\end{array}$ & Approach \\
\hline \multicolumn{7}{|c|}{ Top-down approach } \\
\hline $\begin{array}{l}{ }^{1} \text { LaMontagne et } \\
\text { al. }(2010)\end{array}$ & Australia & Job Strain & $\begin{array}{l}\text { To estimate the costs in the Australian } \\
\text { workforce for job strain-attributable } \\
\text { depression versus all other depression, as } \\
\text { an indication of the potential economic } \\
\text { benefit }\end{array}$ & $\begin{array}{l}\text { Australian National } \\
\text { Survey of Mental } \\
\text { Health and } \\
\text { Wellbeing (2007) }\end{array}$ & $\begin{array}{l}18.6 \% \text { (Male) \& } 25.5 \% \\
\text { (Female) experience Job } \\
\text { Strain }\end{array}$ & $\begin{array}{l}\text { Prevalence- } \\
\text { based; } \\
\text { Incidence- } \\
\text { based }\end{array}$ \\
\hline $\begin{array}{l}{ }^{2} \text { McTernan et al. } \\
(2013)\end{array}$ & Australia & $\begin{array}{l}\text { Job Strain } \\
\text { with bullying }\end{array}$ & $\begin{array}{l}\text { To estimate the contribution of job strain and } \\
\text { bullying to depression-related loss in } \\
\text { productivity }\end{array}$ & $\begin{array}{l}\text { Australian } \\
\text { Workplace } \\
\text { Barometer (2009-10) }\end{array}$ & $22.5 \%$ experience Job Strain & $\begin{array}{l}\text { Prevalence- } \\
\text { based }\end{array}$ \\
\hline${ }^{3}$ Juel et al. (2008) & Denmark & Job Strain & $\begin{array}{l}\text { To calculate the annual resource } \\
\text { consumption in the health service, and } \\
\text { production loss attributable to ill-health } \\
\text { related to psychosocial job strain }\end{array}$ & $\begin{array}{l}\text { Danish Health } \\
\text { Interview Survey } \\
(2000)\end{array}$ & $2 \%$ experience Job Strain & $\begin{array}{l}\text { Prevalence- } \\
\text { based }\end{array}$ \\
\hline \multirow{2}{*}{$\begin{array}{l}{ }^{4} \text { Béjean \& Sultan- } \\
\text { Taieb (2005) }\end{array}$} & \multirow{2}{*}{ France } & \multirow{2}{*}{ Job Strain } & \multirow{2}{*}{$\begin{array}{l}\text { To evaluate the costs of work-related stress } \\
\text { in France related to CVD, depression, and } \\
\text { MSD, using two methodological hypotheses }\end{array}$} & \multirow{2}{*}{$\begin{array}{l}\text { Third European } \\
\text { Survey on Working } \\
\text { Conditions (2000) }\end{array}$} & $\begin{array}{l}20.8 \% \text { (Male) \& } 13.6 \% \\
\text { (Female) experience Job } \\
\text { Strain } 75 \% \text { of the time }\end{array}$ & \multirow{2}{*}{$\begin{array}{l}\text { Prevalence- } \\
\text { based }\end{array}$} \\
\hline & & & & & $\begin{array}{l}27.3 \% \text { (Male) \& } 17 \% \\
\text { (Female) experience Job } \\
\text { Strain } 50 \% \text { of the time }\end{array}$ & \\
\hline $\begin{array}{l}\text { 5Sultan-Taïeb et } \\
\text { al. (2013) }\end{array}$ & France & Job Strain & $\begin{array}{l}\text { To estimate the costs of CVDs and mental } \\
\text { disorders, attributable to job strain exposure } \\
\text { in France in } 2003 \text { from a societal } \\
\text { perspective }\end{array}$ & $\begin{array}{l}\text { French Medical } \\
\text { Monitoring of Risks } \\
\text { Survey (2003) }\end{array}$ & $23.2 \%$ experience Job Strain & $\begin{array}{l}\text { Prevalence- } \\
\text { based }\end{array}$ \\
\hline $\begin{array}{l}{ }^{6} \text { Trontin et al. } \\
(2010)\end{array}$ & France & Job Strain & $\begin{array}{l}\text { To assess the social cost of job stress on a } \\
\text { national scale. }\end{array}$ & $\begin{array}{l}\text { Fourth European } \\
\text { Survey on Working } \\
\text { Conditions (2005) }\end{array}$ & $\begin{array}{l}10.6 \% \text { (Male) \& } 12.4 \% \\
\text { (Female) experience Job } \\
\text { Strain }\end{array}$ & $\begin{array}{l}\text { Prevalence- } \\
\text { based }\end{array}$ \\
\hline $\begin{array}{l}\text { 7Levi \& Lunde- } \\
\text { Jensen (1996) }\end{array}$ & Sweden & Job Strain & $\begin{array}{l}\text { To develop a model for assessing the costs } \\
\text { of stress at work at a national level. }\end{array}$ & $\begin{array}{l}\text { First European } \\
\text { Survey of the } \\
\text { Working } \\
\text { Environment (1991- } \\
\text { 92) }\end{array}$ & $\begin{array}{l}9-12 \% \text { (Male) \& } 9-11 \% \\
\text { (Female) experience Job } \\
\text { Strain }\end{array}$ & $\begin{array}{l}\text { Prevalence- } \\
\text { based }\end{array}$ \\
\hline${ }^{8}$ Goh et al. (2016) & $\begin{array}{l}\text { United } \\
\text { States }\end{array}$ & $\begin{array}{l}\text { Workplace } \\
\text { Stressors }\end{array}$ & $\begin{array}{l}\text { To estimate the aggregate contribution of } \\
\text { ten specific workplace factors to overall } \\
\text { mortality and health spending in the United } \\
\text { States }\end{array}$ & $\begin{array}{l}\text { The General Social } \\
\text { Survey }(2002,2006 \text {, } \\
2010)\end{array}$ & $\begin{array}{l}7.9-17.4 \% \text { (Male) \& 9.3-34.5\% } \\
\text { (Female) experience } \\
\text { workplace stressors }\end{array}$ & $\begin{array}{l}\text { Prevalence- } \\
\text { based }\end{array}$ \\
\hline
\end{tabular}




\section{Bottom-up approach}

\begin{tabular}{|c|c|c|c|c|c|c|}
\hline $\begin{array}{l}{ }^{9} \text { SafeWork } \\
\text { Australia (2012) }\end{array}$ & Australia & $\begin{array}{l}\text { Mental } \\
\text { stress }\end{array}$ & $\begin{array}{l}\text { To estimate the cost of work-related injury } \\
\text { and illness to Australia }\end{array}$ & $\begin{array}{l}\text { Australian Work } \\
\text { Related Injuries } \\
\text { Survey }(2009-10)\end{array}$ & $\mathrm{n} / \mathrm{a}$ & $\begin{array}{l}\text { Incidence- } \\
\text { based }\end{array}$ \\
\hline $\begin{array}{l}{ }^{10} \text { Ramaciotti \& } \\
\text { Perriard (2003) }\end{array}$ & Switzerland & $\begin{array}{l}\text { Stress in } \\
\text { working } \\
\text { population }\end{array}$ & $\begin{array}{l}\text { To investigate the extent of the stress in the } \\
\text { working Swiss population and the costs } \\
\text { incurred. }\end{array}$ & $\begin{array}{l}\text { Survey part of study } \\
(1998)\end{array}$ & $26.6 \%$ report feeling stressed & $\begin{array}{l}\text { Prevalence- } \\
\text { based }\end{array}$ \\
\hline${ }^{11}$ HSE (2013) & $\begin{array}{l}\text { United } \\
\text { Kingdom }\end{array}$ & $\begin{array}{l}\text { Stress, } \\
\text { Depression } \\
\text { \& Anxiety }\end{array}$ & $\begin{array}{l}\text { To cost, the injury and ill health outcomes } \\
\text { associated with health and safety working } \\
\text { conditions }\end{array}$ & $\begin{array}{l}\text { UK Labour Force } \\
\text { Survey (2008-11) }\end{array}$ & 222,000 number of cases & $\begin{array}{l}\text { Incidence- } \\
\text { based }\end{array}$ \\
\hline${ }^{12} \mathrm{SCMH}(2007)$ & $\begin{array}{l}\text { United } \\
\text { Kingdom }\end{array}$ & $\begin{array}{l}\text { Stress, } \\
\text { Depression } \\
\text { \& Anxiety }\end{array}$ & $\begin{array}{l}\text { To identify and quantify all the key effects of } \\
\text { mental ill health and stress at work }\end{array}$ & $\begin{array}{l}\text { UK Self-Reported } \\
\text { Work-Related IIIness } \\
(2005-06)\end{array}$ & $\begin{array}{l}10.5 \text { million working days lost } \\
\text { due to 'stress, depression \& } \\
\text { anxiety' }\end{array}$ & $\begin{array}{l}\text { Incidence- } \\
\text { based }\end{array}$ \\
\hline \multicolumn{7}{|c|}{ Deductive approach } \\
\hline $\begin{array}{l}{ }^{13} \text { Chandola } \\
(2010)\end{array}$ & $\begin{array}{l}\text { United } \\
\text { Kingdom }\end{array}$ & Work stress & $\begin{array}{l}\text { To assess the economic cost of work stress } \\
\text { to Britain }\end{array}$ & $\begin{array}{l}\text { UK Labour Force } \\
\text { Survey (2002) }\end{array}$ & $35 \%$ of all health complaints & $\begin{array}{l}\text { Prevalence- } \\
\text { based }\end{array}$ \\
\hline $\begin{array}{l}{ }^{14} \text { European } \\
\text { Commission } \\
(2000)\end{array}$ & $\begin{array}{l}\text { EU-15 } \\
\text { Member } \\
\text { States }\end{array}$ & $\begin{array}{l}\text { Work-related } \\
\text { stress }\end{array}$ & $\begin{array}{l}\text { To provide a global attempt to estimate the } \\
\text { societal costs for work-related stress at a } \\
\text { European level. }\end{array}$ & $\begin{array}{l}\text { Levi \& Lunde- } \\
\text { Jensen from } \\
\text { Sweden (1996) }\end{array}$ & $10 \%$ of all health complaints & $\begin{array}{l}\text { Prevalence- } \\
\text { based }\end{array}$ \\
\hline $\begin{array}{l}{ }^{15} \text { Shain et al. } \\
(2008)\end{array}$ & Canada & $\begin{array}{l}\text { Psychosocial } \\
\text { hazards }\end{array}$ & $\begin{array}{l}\text { To estimate the money per annum saved by } \\
\text { discretionary modifications to the } \\
\text { organization and management of work to } \\
\text { make it less injurious to employee mental } \\
\text { health }\end{array}$ & $\begin{array}{l}\text { Levi \& Lunde- } \\
\text { Jensen from } \\
\text { Sweden (1996) }\end{array}$ & $\begin{array}{l}10-25 \% \text { of all health } \\
\text { complaints }\end{array}$ & $\begin{array}{l}\text { Prevalence- } \\
\text { based }\end{array}$ \\
\hline
\end{tabular}


Table 3: Costs of work-related stress

\begin{tabular}{|c|c|c|c|c|c|c|c|c|}
\hline & \multirow[b]{2}{*}{ Definition } & \multirow{2}{*}{$\begin{array}{l}\text { Cost (Year } \\
\text { of Cost) }\end{array}$} & \multirow[b]{2}{*}{2014 USD } & \multirow{2}{*}{$\begin{array}{l}\text { Cost per } \\
\text { Worker }\end{array}$} & \multicolumn{2}{|c|}{ Direct Costs } & \multirow[b]{2}{*}{ Indirect Costs } & \multirow{2}{*}{$\begin{array}{l}\text { Intangible } \\
\text { Costs }\end{array}$} \\
\hline & & & & & Healthcare & $\begin{array}{l}\text { Non- } \\
\text { healthcare }\end{array}$ & & \\
\hline \multicolumn{9}{|l|}{ Top-down studies } \\
\hline $\begin{array}{l}\text { 'LaMontagne et al. } \\
(2010) ; \\
\text { Australia }\end{array}$ & $\begin{array}{l}\text { Job Strain } \\
\text { (High } \\
\text { demands, low } \\
\text { control) }\end{array}$ & $\begin{array}{l}\text { AU\$730 } \\
\text { million } \\
(2007)\end{array}$ & $\$ 580$ million & $\$ 46.68$ & $\begin{array}{l}\text { Antidepressant } \\
\text { medication; Mental } \\
\text { health-related health } \\
\text { service use }\end{array}$ & & $\begin{array}{l}\text { Sickness absence } \\
\text { (FCM); Turnover (FCM) }\end{array}$ & \\
\hline $\begin{array}{l}{ }^{2} \text { McTernan et al. } \\
\text { (2013); } \\
\text { Australia }\end{array}$ & $\begin{array}{l}\text { Job Strain } \\
\text { (High } \\
\text { demands, low } \\
\text { control) with } \\
\text { bullying }\end{array}$ & $\begin{array}{l}\$ 294.5 \\
\text { million } \\
(2009)\end{array}$ & $\begin{array}{l}\$ 221.13 \\
\text { million }\end{array}$ & $\$ 17.79$ & & & $\begin{array}{l}\text { Presenteeism (FCM); } \\
\text { Sickness absence } \\
(\text { FCM })\end{array}$ & \\
\hline \multirow{2}{*}{$\begin{array}{l}\text { 3Juel et al. (2008); } \\
\text { Denmark }\end{array}$} & \multirow{2}{*}{$\begin{array}{l}\text { Job Strain } \\
\text { (High } \\
\text { demands, low } \\
\text { control) }\end{array}$} & $\begin{array}{l}\text { DKK } 14.64 \\
\text { billion }(2005)\end{array}$ & $\begin{array}{l}\$ 245 \text { million- } \\
1.46 \text { billion }\end{array}$ & $\begin{array}{l}\$ 130.08- \\
777.26\end{array}$ & \multirow{2}{*}{\multicolumn{2}{|c|}{$\begin{array}{l}\text { Hospital visits; Primary } \\
\text { care visits; Premature } \\
\text { death; Primary care }\end{array}$}} & \multirow{2}{*}{\multicolumn{2}{|c|}{$\begin{array}{l}\text { Pension (FCM/HCM); } \\
\text { Premature death (FCM/ } \\
\text { HCM); Sickness } \\
\text { absence (HCM) }\end{array}$}} \\
\hline & & $\begin{array}{l}\text { DKK } 2.45 \\
\text { billion (2005) }\end{array}$ & & & & & & \\
\hline \multirow{2}{*}{$\begin{array}{l}{ }^{4} \text { Bejean \& Sultan- } \\
\text { Taieb (2005); } \\
\text { France }\end{array}$} & \multirow{2}{*}{$\begin{array}{l}\text { Job Strain } \\
\text { (High } \\
\text { demands, low } \\
\text { control) }\end{array}$} & $\begin{array}{l}€ 1.17-1.62 \\
\text { billion }(2000)\end{array}$ & $\begin{array}{l}\$ 1.83-3.08 \\
\text { billion }\end{array}$ & $\begin{array}{l}\$ 60.94- \\
102.39\end{array}$ & \multirow{2}{*}{$\begin{array}{l}\text { Medical \& Ambulatory } \\
\text { care }\end{array}$} & & \multirow{2}{*}{$\begin{array}{l}\text { Premature death (HCM/ } \\
\text { CLYL); Sickness } \\
\text { absence (FCM) }\end{array}$} & \\
\hline & & $\begin{array}{l}€ 1.37-1.97 \\
\text { billion }(2000)\end{array}$ & & & & & & \\
\hline $\begin{array}{l}{ }^{5} \text { Sultan-Taieb et al. } \\
\text { (2013); } \\
\text { France }\end{array}$ & $\begin{array}{l}\text { Job Strain } \\
\text { (High } \\
\text { demands, low } \\
\text { control) }\end{array}$ & $\begin{array}{l}€ 1.84-2.97 \\
\text { billion (2003) }\end{array}$ & $\begin{array}{l}\$ 2.7-4.35 \\
\text { billion }\end{array}$ & $\begin{array}{l}\$ 89.85- \\
145.03\end{array}$ & $\begin{array}{l}\text { Medical (Consumption } \\
\text { of medical goods and } \\
\text { services) }\end{array}$ & & $\begin{array}{l}\text { Premature death } \\
(\mathrm{HCM}) ; \text { Sickness } \\
\text { absence (FCM) }\end{array}$ & \\
\hline $\begin{array}{l}{ }^{6} \text { Trontin et al. (2010); } \\
\text { France }\end{array}$ & $\begin{array}{l}\text { Job Strain } \\
\text { (High } \\
\text { demands, low } \\
\text { control) }\end{array}$ & $\begin{array}{l}€ 1.9-3 \\
\text { billion (2007) }\end{array}$ & $\begin{array}{l}\$ 2.54-4 \\
\text { billion }\end{array}$ & $\begin{array}{l}\$ 84.41- \\
\$ 133.28\end{array}$ & Medical care & & $\begin{array}{l}\text { Early death }(\mathrm{HCM}) \text {; } \\
\text { Retirement }(\mathrm{HCM}) ; \\
\text { Sickness absence } \\
(\mathrm{FCM})\end{array}$ & \\
\hline $\begin{array}{l}{ }^{7} \text { Levi \& Lunde- } \\
\text { Jensen (1996); } \\
\text { Sweden }\end{array}$ & $\begin{array}{l}\text { Job Strain } \\
\text { (High } \\
\text { demands, low } \\
\text { control) }\end{array}$ & $\begin{array}{l}\text { ECU } 450 \\
\text { million } \\
(1993)\end{array}$ & $\$ 703$ million & $\$ 136.71$ & $\begin{array}{l}\text { Healthcare and } \\
\text { rehabilitation costs }\end{array}$ & & $\begin{array}{l}\text { Premature death (LPO); } \\
\text { Retirement (LPO); } \\
\text { Sickness absence } \\
\text { (FCM) }\end{array}$ & \\
\hline
\end{tabular}




\begin{tabular}{|c|c|c|c|c|c|c|c|c|}
\hline $\begin{array}{l}{ }^{8} \text { Goh et al. (2016); } \\
\text { United States }\end{array}$ & $\begin{array}{l}\text { Workplace } \\
\text { stressors } \\
\text { (Layoffs \& } \\
\text { unemployment; } \\
\text { no health } \\
\text { insurance; shift } \\
\text { work; long } \\
\text { work hours; job } \\
\text { insecurity, } \\
\text { work-family } \\
\text { conflict; low job } \\
\text { control; high } \\
\text { job demands; } \\
\text { low social } \\
\text { support; low } \\
\text { org. justice) }\end{array}$ & $\begin{array}{l}\text { US } \$ 187 \\
\text { billion (2011) }\end{array}$ & $\$ 187$ billion & $\$ 1211.84$ & Medical expenditure & & & \\
\hline \multicolumn{9}{|l|}{ Bottom-up studies } \\
\hline $\begin{array}{l}{ }^{9} \text { SafeWork Australia } \\
\text { (2012); } \\
\text { Australia }\end{array}$ & Mental stress & $\begin{array}{l}\$ 5.3 \text { billion } \\
(2009)\end{array}$ & $\$ 3.98$ billion & $\$ 320.14$ & Medical; Rehabilitation & $\begin{array}{l}\text { Compensation } \\
\text { \& welfare; } \\
\text { Funeral; } \\
\text { Investigation; } \\
\text { Legal; Tax } \\
\text { loss; Travel; } \\
\text { Penalties }\end{array}$ & $\begin{array}{c}\text { Retirement (HCM); } \\
\text { Sickness absence } \\
\text { (FCM); Turnover (FCM) }\end{array}$ & \\
\hline $\begin{array}{l}{ }^{10} \text { Ramaciotti \& } \\
\text { Perriard (2003); } \\
\text { Switzerland }\end{array}$ & $\begin{array}{l}\text { Stress in } \\
\text { working } \\
\text { population }\end{array}$ & $\begin{array}{l}\text { CHF } 4.19 \\
\text { billion (1999) }\end{array}$ & $\$ 3.33$ billion & $\$ 701.14$ & $\begin{array}{l}\text { Doctor visits; Hospital } \\
\text { visits; Self-medication }\end{array}$ & & $\begin{array}{c}\text { Sickness absence } \\
\text { (FCM) }\end{array}$ & \\
\hline $\begin{array}{l}{ }^{11} \mathrm{HSE} \text { (2013): } \\
\text { United Kingdom }\end{array}$ & $\begin{array}{l}\text { Stress, } \\
\text { Depression \& } \\
\text { Anxiety }\end{array}$ & $\begin{array}{l}£ 3.66 \text { billion } \\
(2011)\end{array}$ & $\$ 5.42$ billion & $\$ 164.58$ & $\begin{array}{l}\text { NHS treatment and } \\
\text { rehabilitation; } \\
\text { Prescription }\end{array}$ & $\begin{array}{l}\text { Administration; } \\
\text { Fines; } \\
\text { Funeral; } \\
\text { Home; Income } \\
\text { loss; } \\
\text { Insurance; } \\
\text { Travel }\end{array}$ & $\begin{array}{l}\text { Turnover (FCM); Work } \\
\text { reorganization (FCM) }\end{array}$ & $\begin{array}{l}\text { Non- } \\
\text { financial } \\
\text { human } \\
\text { costs }\end{array}$ \\
\hline $\begin{array}{l}{ }^{12} \text { SCMH (2007); } \\
\text { United Kingdom }\end{array}$ & $\begin{array}{l}\text { Stress, } \\
\text { Depression \& } \\
\text { Anxiety }\end{array}$ & $\begin{array}{l}£ 1.26 \text { billion } \\
(2006)\end{array}$ & $\$ 2.18$ billion & $\$ 66.35$ & & & $\begin{array}{l}\text { Sickness absence } \\
\text { (FCM) }\end{array}$ & \\
\hline
\end{tabular}




\section{Deductive approach}

${ }^{3}$ Chandola (2010);

Work stress

(Stress,

£7- $12.6 \quad$ \$13.12- \$398.10-

$\$ 13.12-$

United Kingdom

(Stress,

billion (200

Anxiety)

Work-related

${ }^{14}$ European

stress

Commission (2000); $\quad$ (High

demands, low

control)

$€ 20$ billion

(1999)

$\mathrm{n} / \mathrm{a}^{\mathrm{a}}$

Psychosocia

${ }^{15}$ Shain et al. (2008);

hazards

\$2.97-11 \$2.59- $9.59 \quad \$ 131.30$

(High

$\begin{array}{lll}\$ 2.97-11 & \$ 2.59-9.59 & \$ 131.30 \\ \text { billion (1998) } & \text { billion } & 486.33\end{array}$

Mental health care

Social

services

Economic

GDP control)

aThe inability to obtain purchase power parities for the EU as a whole meant it was not possible to convert the inflated Euro cost into US dollars. 
Table 4: Marks received on quality assessment criteria rating of the fourteen studies

\begin{tabular}{|c|c|c|c|c|c|c|c|c|c|c|c|c|c|c|c|}
\hline \multirow[b]{2}{*}{ Approach } & \multirow[b]{2}{*}{ TD } & \multirow[b]{2}{*}{ TD } & \multirow[b]{2}{*}{ TD } & \multirow[b]{2}{*}{ TD } & \multirow[b]{2}{*}{ TD } & \multirow[b]{2}{*}{ TD } & \multirow[b]{2}{*}{ TD } & \multicolumn{2}{|c|}{ Articles } & \multirow[b]{2}{*}{$\mathrm{BU}$} & \multirow[b]{2}{*}{$\mathrm{BU}$} & \multirow[b]{2}{*}{$\mathrm{BU}$} & \multirow[b]{2}{*}{ DD } & \multirow[b]{2}{*}{$\mathrm{DD}$} & \multirow[b]{2}{*}{$\mathrm{DD}$} \\
\hline & & & & & & & & TD & $\mathrm{BU}$ & & & & & & \\
\hline Quality Assessment Criteria & 1 & 2 & 3 & 4 & 5 & 6 & 7 & 8 & 9 & 10 & 11 & 12 & 13 & 14 & 15 \\
\hline $\begin{array}{l}\text { 1. Was a clear definition of the } \\
\text { illness given? }\end{array}$ & 1 & 2 & 2 & 2 & 1 & 1 & 2 & 1 & 0 & 0 & 0 & 0 & 0 & 0 & 0 \\
\hline $\begin{array}{l}\text { 2. Were epidemiological } \\
\text { sources carefully described? }\end{array}$ & 1 & 2 & 1 & 2 & 2 & 2 & 1 & 2 & 2 & 2 & 2 & 2 & 0 & 1 & 0 \\
\hline $\begin{array}{l}\text { 3. Were costs sufficiently } \\
\text { disaggregated? }\end{array}$ & 0 & 0 & 2 & 2 & 2 & 2 & 0 & 2 & 0 & 2 & 0 & 2 & 0 & 0 & 0 \\
\hline $\begin{array}{l}\text { 4. Were activity data } \\
\text { appropriately assessed? }\end{array}$ & 2 & 2 & 2 & 2 & 2 & 2 & 2 & 2 & 2 & 0 & 1 & 2 & 0 & 1 & 0 \\
\hline $\begin{array}{l}5 . \text { Were the sources of all cost } \\
\text { values analytically described? }\end{array}$ & 1 & 2 & 2 & 1 & 2 & 0 & 0 & 1 & 2 & 2 & 2 & 0 & 0 & 1 & 0 \\
\hline $\begin{array}{l}\text { 6. Were unit costs } \\
\text { appropriately valued? } \\
\text { 7. Were the methods adopted }\end{array}$ & 1 & 1 & 2 & 1 & 1 & 0 & 1 & 1 & 2 & 2 & 2 & 1 & 0 & 0 & 0 \\
\hline carefully explained? & 2 & 2 & 2 & 2 & 2 & 0 & 1 & 2 & 2 & 2 & 2 & 2 & 2 & 2 & 2 \\
\hline $\begin{array}{l}\text { 8. Were costs discounted? } \\
\text { 9. Were the major } \\
\text { assumptions tested in a }\end{array}$ & 2 & NA & 2 & 2 & 2 & NA & 1 & NA & NA & NA & 2 & NA & NA & NA & NA \\
\hline $\begin{array}{l}\text { sensitivity analysis? } \\
10 . \text { Was the presentation of } \\
\text { study results consistent with }\end{array}$ & 2 & 1 & 2 & 2 & 2 & 1 & 0 & 2 & 2 & 1 & 1 & 0 & 0 & 0 & 2 \\
\hline the methodology of study? & 1 & 2 & 0 & 2 & 2 & 2 & 1 & 2 & 2 & 2 & 2 & 2 & 0 & 2 & 0 \\
\hline Total Score (Out of 20) & $\begin{array}{c}13 \\
\text { Average }\end{array}$ & 16 & 17 & 18 & 18 & $\begin{array}{c}11 \\
\text { Average }\end{array}$ & $\begin{array}{c}9 \\
\text { Average }\end{array}$ & 17 & 16 & $\begin{array}{c}14 \\
\text { Average }\end{array}$ & $\begin{array}{c}14 \\
\text { Average }\end{array}$ & $\begin{array}{c}12 \\
\text { Average }\end{array}$ & 2 & $\begin{array}{c}8 \\
\end{array}$ & 4 \\
\hline
\end{tabular}

Legend: 2 marks for fully met criteria; 1 mark for partially met criteria; 0 marks for criteria not met; NA: Not applicable; TD: Top-down; BU: Bottom-up;

DD: Deductive

Scoring: 0-7: Poor quality; 8-15: Average quality; 16-20: Good quality. 
Flgure 1. The review process based on PRISMA flow diagram.
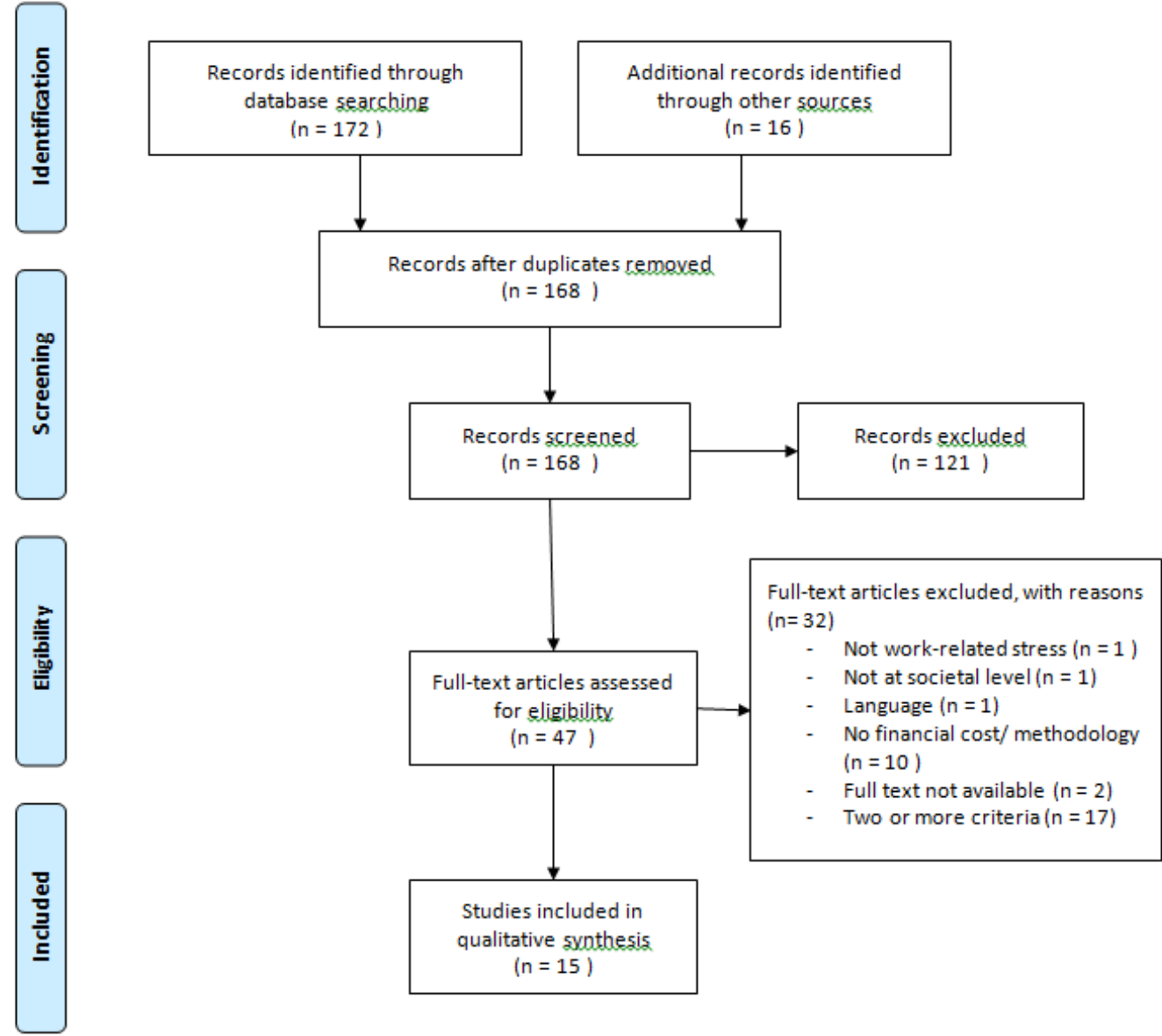
Figure 2: Proportion of medical and production loss-related (sickness absence, premature death and premature workforce exit) costs

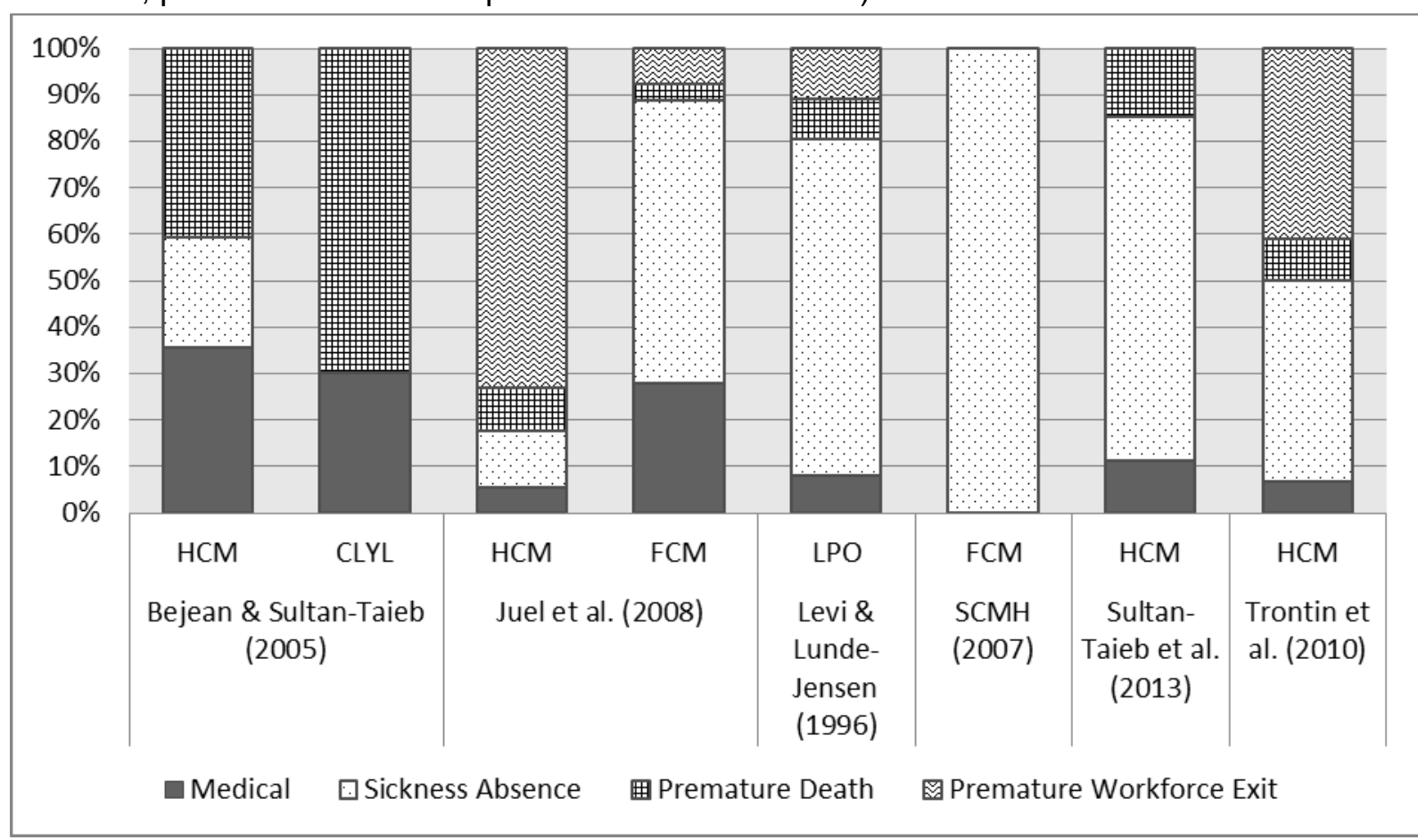

"Notes: HCM, Human capital method; FCM, Friction cost method; LPO, Loss-ofpotential-output; CLYL, Cost-of-life-years-lost. 
Appendix: Cost of Illness Study Quality Assessment Checklist

\begin{tabular}{lc}
\hline & $\begin{array}{c}\text { Circle } \\
\text { 1. Was a clear definition of the illness given? } \\
\text { answer }\end{array}$ \\
\hline - $\quad$ Definition of work-related stress (or psychosocial hazard provided) & YnS/NO \\
epidemiological / prevalence data source (e.g., items used, scoring) & Score two if both of the above are met. Score one if only one of \\
the above is met. Score zero if none are met. & Score: \\
\hline $\begin{array}{l}\text { 2. Were epidemiological sources carefully described? } \\
\text { - The source of the epidemiological data is described. This needs to be } \\
\text { more than just a reference, and allude at the least to sample size and } \\
\text { geographical location. }\end{array}$ & YES/NO \\
Any shortcomings and limitations (e.g., drawing on data from a different \\
country) needs to be appropriately justified. \\
$\quad \begin{array}{l}\text { Score two if both of the above are met. Score one if only one of } \\
\text { the above is met. Score zero if none are met. }\end{array}$
\end{tabular}

3. Were costs sufficiently disaggregated?

- $\quad$ Are total costs disaggregated (broken) into appropriate sub-costs?

YES/NO

(Could/ should these costs have been broken down further?)

Score two if the above is met. Score zero if it is not met.

Score:

\section{Were activity data appropriately assessed?}

Is data linking stress prevalence/ incidence or stress behaviours with health or work outcomes reported? The data can manifest as odds ratios or relative risk, or the data demonstrating stressed workers having $X$ amount of sick days or $Y$ reduction in productivity.

- Activity data is provided

YES/NO

- $\quad$ Source is provided

Score two if both the above are met. Score one if only one of the above is met. Score zero if none are met.

Score:

5. Were the sources of all cost values analytically described?

- The source of every cost is provided

YES/NO

- $\quad$ Sampling variation is considered. This means that costs account for differences (e.g., gender, age, occupational)

YES/NO

Score two if both the above are met. Score one if only one of the above is met. Score zero if none are met.

Score: 


\section{Were unit costs appropriately valued?}

- Unit costs are identified (e.g., cost per day, average cost of medication)

YES/NO

- Unit costs are appropriate proxy for the component (i.e., sickness absence)

- Unit costs sources are provided

Score two if both the above are met. Score one if one or two the criteria above are met. Score zero if none are met.

Score:

\section{Were the methods adopted carefully explained?}

- $\quad$ Study methods were displayed in a clear, transparent manner

- If a valid and reliable scale/measure was used OR if such scales/measures were not used, justification was given for the measures/scales used

Score two if both the above are met. Score one if only one of the above is met. Score zero if none are met.

\section{Were costs discounted ${ }^{1}$ ?}

When costs extend over a one year period, studies should discount should be discounted to reflect future costs having less of a value than present day costs. The discounting rate needs to be justified to fully meet this criterion.

- Costs extend beyond one year, and cost figures are discounted.

- Justification for discount rate was provided

Score two if both the above are met. Score one if only one of the above is met. Score zero if none are met.

Score:

\section{Were the major assumptions tested in a sensitivity analysis ${ }^{2}$ ?}

The study should vary in range key variables that may influence outcome (e.g., prevalence, unit costs, etc.). Studies with at least 2-way analysis (i.e., change of two key variables) fully meet this criteria, those that only vary one key variable only partially meet this criterion.

- 2-way analysis was conducted (i.e., change of two key variables)

- 1-way analysis was conducted (i.e., change of only one key variable) Score two if a 2-way analysis was conducted. Score one if a 1way analysis was conducted. Score zero if neither was conducted.

Score:

\section{Was the presentation of study results consistent with the methodology} of study?

The presentation of $\mathrm{COI}$ results should be consistent with collected data and should disaggregate results into as many components as possible with full explanations given for clarity.

- Do the results match the aim of the study?

- $\quad$ Are the conclusions made consistent with the results, accounting for the methods / sample?

Score two if both the above are met. Score one if only one of the above is met. Score zero if none are met.

Score:

Total summed score:

Study quality assessment rating [Poor quality (0-7), average quality (8-15), high quality (16-20)]:

${ }^{1}$ Discounting makes current costs and benefits worth more than those occurring in the future because there is an opportunity cost to spending money now and a desire to enjoy benefits now rather than in the future. e.g. If the money was invested (wisely) now it would be worth more in one year's time.

2 Sensitivity analysis is the standard method of allowing for uncertainty in economic evaluations. It involves varying the values of key parameters, one at a time, to see if the results of the evaluation are sensitive to the assumptions made. 
